Pecvnia, 10 (2010), pp. 299-346

\title{
La retribución a la Residencia Anual de los Canónigos en la Iglesia de Toledo (S. XVI)
}

\author{
Susana Villaluenga de Gracia \\ Susana.Villaluenga@uclm.es \\ Universidad de Castilla-La Mancha \\ Fac. de Ciencias Jurídicas y Sociales de Toledo \\ Cobertizo de San Pedro Mártir, s/n \\ Aceptado: Febrero 2010 \\ 45071 Toledo (España)
}

Este artículo pretende continuar con el estudio del sistema retributivo del clero catedralicio de Toledo, ahondado esta vez en el vestuario de los canónigos.

En la catedral de Toledo, al igual que en otras catedrales, una parte de las rentas eclesiásticas se destinaba al clero catedralicio para cubrir el alimento (refitor) y el vestido (vestuario). El primero concernía a la consunción y el segundo a la perfección.

El vestuario era la principal renta que recibía un canónigo de la Iglesia de Toledo, haciéndolo en orden a la dignidad conferida. Procedía de los diezmos de pan y vino que se recogían en el arzobispado y remuneraba la residencia anual. Se complementaba con otros
The purpose of this paper is to continue studying the compensation system cathedral clergy of Toledo in the sixteenth century, this time on the vestuario of the canons.

In this cathedral, as in one other, a part of the income was allocated to the cathedral clergy to cover the food (refitor) and clothing (vestuario). The first one was concerning the consumption and the second one to the perfection.

The vestuario was the main income that was receiving a canon of the Church of Toledo, so in order to dignity conferred. It was coming from the tithes of wheat and wine which were collected in the archbishopric of Toledo. Each canon received, together with income from 
recursos como las rentas procedentes del préstamo de Baza y el de Hita.

Palabras clave: vestuario, canónigo, cabildo, catedral, Toledo. refitor, the vestuario as an incentive for annual residency, along with other additional income from various loans as of Baza and de Hita.

Key words: canon, chapter, cathedral, Toledo.

\section{EL VESTUARIO DE LOS CANÓNIGOS}

El servicio religioso en las catedrales se sostenía con las rentas generadas por el patrimonio afecto a la corporación, los diezmos y oblaciones. El de la catedral de Toledo lo hacía con las rentas de la mesa capitular adjudicada al clero catedral desde la división del patrimonio entre éste y el arzobispo en 1138. Este año asistimos, como en otros cabildos hispanos, a una separación de bienes con la división del patrimonio en dos mesas: la arzobispal (arzobispo) y la capitular (cabildo).

Con la separación de las mesas, la cesión que hizo a la capitular el arzobispo Raimundo de Sauvetat agrupó, entre otras rentas y propiedades: a) la mitad del pan y vino de las tercias de las iglesias de Toledo; b) la tercera parte de las rentas presentes y futuras, de las tierras cultivadas o por cultivar, de las viñas labradas y no labradas, molinos, baños, hornos, tiendas, alhóndigas, pesquerías, canales, portazgos y diezmos del Emperador, la mitad de la alcabala de Talavera, la tercera parte de las rentas ${ }^{1}$ de Talavera, Maqueda, Santa Olalla, Escalona, Alhamín, Olmos, Canales, Calatalifa, Madrid, Talamanca, Buitrago, Guadalajara, Alcalá, Hita, Peñafora, Beleña, Cogolludo y de todas las villas pobladas y por poblar de la diócesis de Toledo, la mitad de la limosna ofrecida por los muertos hasta veinte sueldos, la de las ofrendas de animales, el oro, la plata, vestidos y la tercera parte del aceite de las tercias, habas y garbanzos; y c) de las donaciones de heredades, dos partes eran para el arzobispo y una para el Cabildo².

El tercio de la tercia episcopal de estos lugares. J.F. Rivera Recio (1976) La Iglesia de Toledo en el siglo XII (1086-1208), 2 vols. Roma: Publicaciones del Instituto Español de Historia Eclesiástica, vol. 2, p. 65.

F.J. Hernández (1996) Los cartularios de Toledo. Catálogo documental, $2^{a}$ ed., Madrid: Fundación Ramón Areces, p. 43; J.F. Rivera Recio (1976) La Iglesia de Toledo.., ed. cit., vol. 2, p. 65; y A. González Palencia (1926-1930) Los mozárabes de Toledo en los siglos XII y XIII, vol. 1, Madrid: Instituto de Valencia de Don Juan, pp. 159-160. 
Francisco de Pisa habla de una división en tres partes: la del arzobispo, el cabildo y una tercera adjudicada a los canónigos, instituyendo que fueran treinta ${ }^{3}$ (24 mayores y 6 menores). En referencia a estas dos últimas partes hablamos de una mesa capitular destinada a atender los gastos comunitarios; y de unas rentas para el vestuario de los canónigos ${ }^{4}$. Esto aclararía el que el autor, al tratar la división patrimonial, se refiera a los canónigos mansionarios,

...los que manebant, esto es, vivían en el claustro, y llevaban el vestuario, que es la gruessa de los canonicatos: a diferencia de otros, que aunque recipiebant panem canonice (como dize la constitución) recibian el pan y comida por refectorio, mas no gozauan del vestuario ${ }^{5}$.

Con esto se cubría el alimento y el vestido, conforme al dicho del apóstol: "mientras tengamos comida y vestido, con esto nos contentamos"6. El primero concerniría a la consunción y el segundo a la perfección.

Las rentas del Cabildo quedaron constituidas por tres acervos: el vestuario capitular que equivalía a la gruesa canónica, el refitor repartido a prorrata de la residencia y las caridades o distribuciones inter praesentes procedentes de fundaciones especiales. A esto había que unir las multas recaudadas por el refitor de arrendatarios morosos, distribuidas entre los presentes cada mes ${ }^{7}$.

Los términos de refitor y vestuario provenían de los orígenes de esta comunidad catedralicia, constituida al tiempo de la Reconquista como abadía o priorato benedictino en el que el prelado ejercía de prior y compartía los bienes en el refectorio. A ello, precisamente, se refiere Pedro de Alcocer (1554):

\footnotetext{
4 Rivera Recio fijó el principio de los vestuarios en la desagregación del patrimonio capitular, destinado a atender los gastos de la corporación que con el tiempo se dividiría para manutención, habitación y vestuario, además de para los gastos comunes. J.F. Rivera Recio (1974) "Patrimonio y Señorío de Santa María de Toledo desde el 1086 hasta el 1208", Anales Toledanos, 9, p. 134.

F. de Pisa (1605) op. cit., f.166r.

1 Timoteo, 6:9.

E. Estella (1926) "El fundador de la Catedral de Toledo", Boletín de la Real Academia de Bellas Artes y Ciencias Históricas de Toledo, 26-27, p. 185.
} Toledo: IPIET [1974], f.166r.

F. de Pisa (1605) Descripcion de la imperial ciudad de Toledo. Edic. Facsímil. 


\begin{abstract}
Algunos han pensado que deste poco tiempo, que estos monges del tuuieron la guernacion y regimiento desta Sancta Yglesia quedaron en ellas las señales vestigios, y nombres de refectorio, y vestuarios, que oy ay en ellas, y las capas de coro que traen los canónigos: desde todos santos, a Pascua florida: aunque lo más cierto parece, que es, que quedan estos nombres, por auer sido al començo, los canónigos desta iglesia reglares, militando debaxo de la regla de San Agustin"8.
\end{abstract}

Los que convivían bajo esta Regla no tenían nada como propio sino común, distribuyendo el prepósito la comida y el vestido,

...no a todos por igual, pues no gozáis todos de la misma salud, sino más bien a cada cual según lo necesite. Pues así leéis en los Hechos de los Apóstoles, que «todo lo poseían en común, y se distribuía a cada uno según su propia necesidad» (Hech. 4, 32 y 35$)^{9}$.

El refectorio (refectorium), lugar donde se juntan a comer en las religiones y conventos o donde compartían el alimento sentados a la mesa, relacionado también con el término "refección" o la comida moderada con que se rehacen las fuerzas y espíritus ${ }^{10}$, dio lugar más tarde al término refitor, el departamento encargado de gestionar las rentas de la Mesa, siendo el refitolero la cabeza de este departamento, en alusión al que tenía cuidado del refectorio.

La dotación del vestuario, en principio, estaba justificada por la adquisición de ropas corales. Con el término "vestuario" también se designaba la sacristía, diaconicon para los griegos, el lugar donde se guardaban los vasos y vestiduras sagradas ${ }^{11}$. En la Catedral era la parte

8 P. de Alcocer (1554) Hystoria o descripcion de la imperial çibdad de Toledo. Edic. Facsímil. Toledo: IPET [1973], f.LVIIv.

9 Regla de San Agustín, cap. 1.3. Aunque el título de Regla de San Agustín comprende varios documentos, sólo alguno de ellos fueron escritos por este Padre de la Iglesia. Entre ellos una carta (Carta 211) dirigida a las monjas del convento en que había sido abadesa su hermana y dos sermones (355 y 356) donde se recogen los primeros principios ascéticos de la vida religiosa. Éstos constituyen la base de las constituciones de muchos cabildos, entre ellos del Cabildo isidoriano de León que se rige actualmente por la misma.

Vox refitorio.

10 S. Covarrubias Orozco $(1611 ; 1995)$ Tesoro de la Lengua castellana o española.

11 D. Cavallario (1850) Instituciones de Derecho Canónico, $3^{\mathrm{a}}$ ed., 2 tomos. Madrid-Santiago: Imprenta de don Alejandro Gómez Fuentenebro, T.2, p. 24. 
donde se revestían para salir a celebrar las misas mayores y para las procesiones e incensación de altares en vísperas y laúdes ${ }^{12}$.

El ganar la comida o el vestido estaba vinculado al cumplimiento del servicio prescrito para la renta, pues era "inequidad apoderarse de los frutos eclesiásticos simulando obsequio" (Concilio de Toledo de 1582, Actio tertia, d. XIV) ${ }^{13}$, conforme a la afirmación del apóstol, cada uno recibiría así la merced según su trabajo. De esta forma, los beneficiados recibían lo que correspondía al refitor por la asistencia al rezo de horas canónicas, servicio de semanas, asistencia a aniversarios, etc., complementándose estas rentas anualmente con el superávit ${ }^{14}$. Mientras, el vestuario lo ganaban únicamente los canónigos.

La primera referencia expresa a la dotación del vestuario en la catedral de Toledo podría remontarse a la donación perpetua que el 12 de mayo de 1137, siendo arzobispo don Raimundo de Sauvetat, el Emperador y su mujer doña Berenguela hacen del diezmo de toda la moneda acuñada en Toledo para las vestiduras de los canónigos ${ }^{15}$.

En siglos posteriores el vestuario se consolida como las rentas decimales que llamaban parte de canónigos y que correspondía al pan y vino de todo el arzobispado de Toledo ${ }^{16}$, compartidas con el arzobispo. Éste renunciaría, al tiempo de la intervención del monarca en los diezmos ${ }^{17}$ y la reestructuración del reparto, a parte de sus derechos a favor de los canónigos y del arcediano, cediendo a los primeros el tercio de cuanto le correspondía de pan y de vino ${ }^{18}$.

12 S. Ramón Parro $(1857 ;$ 1978) Toledo en la mano. Toledo: IPIET, ed. facsímil, vol. 1 , p. 546 .

13 J. Tejada y Ramiro (1863) Colección de cánones y de todos los Concilios de la Iglesia de España y de América, T.5. Madrid: Imprenta de don Pedro Montero, p. 464.

14 S. Villaluenga de Gracia (2009) "La remuneración y el control del servicio cultual en la Iglesia de Toledo (S. XVI)", Pecvnia, 8, pp. 325-370.

15 F.J. Hernández (1996) Los cartularios..., op. cit., p. 41.

16 ACT, OF-909, f.256r.

17 Las tercias reales se extraían del tercio de fábrica y correspondía a dos novenos de las rentas decimales. El importe así obtenido fue cedido por la Iglesia con autorización del papado y su destino era sufragar los gastos de la guerra contra el Islam. La primera concesión directa de una ración decimal al rey fue hecha el 15 de abril de 1247 por el Papa Inocencio IV a Fernando III por tres años a causa del asedio de Sevilla. Sobre esta concesión temporal se harían continuas prorrogas hasta el momento en que se convirtió definitivamente en un ingreso ordinario en 1495. M.A. Ladero Quesada (1982) El siglo XV en Castilla. Fuentes de renta y política fiscal. Barcelona: Ariel, p. 67.

18 J.L. Martín "Presentación" en M.L. Guadalupe Beraza (1972) Diezmos de la sede toledana y rentas de la mesa arzobispal (siglo XV). Universidad de Salamanca, p. 18. 
Las rentas de los vestuarios quedaban aseguradas con el diezmo de pan y vino de los arciprestazgos de La Guardia, Ocaña, Illescas, Canales, Rodillas, Montalbán, Talavera, Escalona, Santa Olalla, Maqueda, Madrid, Alcalá, Calatrava, Alcaraz, Talamanca, Alcolea, Guadalajara, Buitrago, Valdelozoya, Hita, Brihuega, Zorita y Almoguera y La Vicaria de la Puebla de Alcocer con Las Cuadrillas ${ }^{19}$. En virtud a esta relación, no llevaban los canónigos parte en el arciprestazgo de Uceda, sólo el arzobispo. Tampoco los canónigos tenían como vestuario el diezmo del pan de las parroquias de Toledo que permanecía adscrito a la mesa capitular y de las que se encargaba el granero. En concreto, éste era el encargado de cobrar un diezmo y medio diezmo del precio en que remataban las rentas de los panes de estas parroquias ${ }^{20}$.

Lo que iba al vestuario procedía del pan de pontifical y no del pan de las tierras ni de lo que correspondía a las posesiones de la Iglesia que pertenecía a la mesa capitular, repartiéndose por raciones a todos los beneficiados según se debía de haber, sin tomar de ello el vestuario.

El vestuario era el estipendio más importante y el principal que recibía un canónigo en Toledo y se repartía entre los canónigos que cumplían con la residencia anual:

...la principal renta que la canongia de Toledo tiene es un vestuario que es la porçion que le cabe de la parte de canonigos en las rentas de los diezmos de panes y vinos de todo el Arzobispado de Toledo esto se reparte todo lo que monta entre los señores canonigos que ganaron vestuario en cada un año ${ }^{21}$.

También era la renta posiblemente más estable. Su estabilidad, tal como sostienen algunos autores, venía garantizada por la seguridad del diezmo que perduraba asentado en una coacción ideológicopolítica ${ }^{22}$.

Los emolumentos que recibía un canónigo permitían a éste llevar una vida acomodada y vivir holgadamente, una forma de distinción social, pero también una necesidad y exigencia de la corporación que les

\footnotetext{
19 El detalle del reparto por arciprestazgos en M.L. Guadalupe Beraza (1972) op. cit.

20 ACT, OF-909, f.166r.

21 ACT, OF-909, f.256r.

22 M. Rodríguez Llopis e I. García Díaz (1994) Iglesia y sociedad feudal. El cabildo de la catedral de Murcia en la Baja Edad Media. Universidad de Murcia, p. 99.
} 
requería un modo de vida de acuerdo al rango que se les había conferido $^{23}$. Esto pedía adoptar una compostura y un talante solemne, adecuando la forma de vida a su dignidad, mostrando decoro en el vivir y en la vestimenta, que les hiciera parecer ante los ojos de las personas como miembros de una comunidad respetable.

En Toledo muchos canónigos como beneficiados desarrollaban, a título personal, una actividad económica importante, pues, a diferencia del clero regular ${ }^{24}$, el secular podía contar con bienes en propiedad y hacer negocios fuera o dentro de la Iglesia. En este último caso no era infrecuente encontrarles participando en los remates de las rentas decimales, en el arrendamiento de casas, dehesas, huertas, etc. propiedad del Cabildo. Esta circunstancia, por otro lado, no era nada diferente a la de otras corporaciones de la misma naturaleza. En BaezaJaén una gran parte de los arrendatarios de las propiedades eclesiásticas eran miembros del Cabildo ${ }^{25}$. En Segovia en el siglo XIV, los arriendos de inmuebles eran tomados frecuentemente por los capitulares para el subarriendo, logrando importantes beneficios personales (del 25 al 50\%) ${ }^{26}$. Esta situación se repetía en el cabildo sevillano ${ }^{27}$, siendo también reconocida la cesión a los capitulares murcianos de los inmuebles para el subarriendo con el fin de que lograran mejoras económicas en sus beneficios $^{28}$.

La presencia del clero y sobre todo de los canónigos por su condición económica privilegiada en los negocios de la Iglesia era bastante frecuente. A pesar de que a los beneficiados de la Iglesia se les prohibía arrendar rentas porque los que estaban al servicio de Dios no debían entrometerse en negocios seglares; esto no se entendía para los que

23 R. Sánchez González (2000) Iglesia y sociedad en la Castilla Moderna. El cabildo catedralicio de la Sede Primada (siglo XVII). Cuenca: Universidad de Castilla-La Mancha, p. 34.

24 Mientras que al clero regular, tal y como reconocía el Concilio de Trento, se prohibía absolutamente la propiedad (sesión XXV, capítulo II), disfrutando en común de las rentas que obtenían del patrimonio, aquéllos las percibían como miembros del colectivo y a título particular. $\mathrm{P}$. Fatjó Gómez (1999) "Organización y gestión de una hacienda eclesiástica en la Cataluña del XVII: la catedral de Barcelona", Revista de Historia Económica, 17, 1, p. 115.

25 J. Rodríguez Molina (1974) "El patrimonio eclesiástico del obispado de BaezaJaén (siglos XIII-XV)", Boletín de Estudios Giennenses, 82, p. 28.

26 M. Santamaría Lancho (1985) "La explotación económica del patrimonio urbano del cabildo catedralicio de Segovia en el siglo XIV", La ciudad hispánica durante los siglos XIIIXIV, Madrid: Universidad Complutense, p. 691.

27 I. Montes Romero-Camacho (1988) Propiedad y explotación de la tierra en la Sevilla de la Baja Edad Media. Sevilla: Fundación Fondo de Cultura de Sevilla, p. 244.

28 M. Rodríguez Llopis e I. García Díaz (1994) op. cit., p. 101. 
quisiesen arrendar las posesiones de la Iglesia y los diezmos de sus propiedades. Hay incluso quien ha visto en esto un interés que iba más allá del personal en la obtención de un beneficio. En el caso del cabildo de Córdoba para la Edad Media, Sanz Sancho ve estas operaciones dentro de una visión de solidaridad y corresponsabilidad económica, apoyándose en la posibilidad de una norma no escrita que llevaba a los capitulares a arrendar los bienes del Cabildo por un valor conforme al estimado de su beneficio capitular ${ }^{29}$.

\section{LA FORMA DE GANAR EL VESTUARIO}

El vestuario constituía la gruesa del canonicato, no servía así, como las distribuciones, para premiar la asistencia a los actos corales, sino que respondía a la congrua sustentación de los residentes y sobre todo remuneraba a los canónigos, una minoría selecta y rectora que contribuiría a la perfección temporal y espiritual de la corporación. Se perdía por irresidencia, es decir, por no asistir nunca al coro, o por faltar algunas veces.

El acervo del vestuario se repartía entre el número de canónigos, 40 en el tiempo que estudiamos, y que fue cambiando como el número de beneficios y oficios en proporción a los recursos capitulares, buscando siempre ajustar el mismo a las rentas de que gozaban y garantizando la correcta asignación de recursos. Este criterio, presente ya en la primera constitución dada por don Raimundo (1138), pretendía que los beneficiados quedaran con una retribución decente, evitando que se dedicaran a otros asuntos para completar su retribución y no atendieran los servicios ${ }^{30}$.

\section{- La residencia anual}

Son los estatutos dados por don Sancho de Aragón los que modifican lo establecido por el legado Juan de Abbeville y fijan la

29 I. Sanz Sancho (2000) "El cabildo catedralicio de Córdoba en la Edad Media", En la España Medieval, 23, p. 222.

30 E. Estella (1926) op. cit., p. 183. 
residencia tal y como llega al siglo $X \mathrm{~V}^{31}$, prorrogándose hasta este período. En virtud a esto, el canónigo ganaba su vestuario si cumplía con la residencia anual, que consistía en asistir al rezo de una de las horas mayores (maitines, misa mayor o vísperas). El tiempo para el cómputo de la residencia iba desde el día de San Miguel de cada año hasta el mismo día del año siguiente, excluido este último. Por tanto, a partir del día de San Miguel de un año se empezaban a ganar los frutos del año siguiente ${ }^{32}$. Por tanto, los frutos del año 1530 se empezaban a ganar desde el día de San Miguel de 1529 y se acababan de ganar las vísperas del día de San Miguel de 1530. Los días antes de la fecha o el día anterior, los canónigos llegaban diligentes a presentar las cédulas de su residencia personal ante el Cabildo ratificadas y firmadas por el partidor ${ }^{33}$.

Era en el libro de horas donde el apuntador iba haciendo registro, junto a los tercios, de cuestiones relativas a los vestuarios: las protestas por residencia, licencias, gracias, privilegios, etc. En el libro de horas de 1583, el 28 de septiembre se advertía que: "este dia a visperas protestaron su residencia anual los señores doctor Navarro y doctor Anaya canónigos"; y el día de San Miguel, el 29 de septiembre, se decía que: "presentose para su vestuario el señor licenciado Bautista Velez" ${ }^{\text {"34 }}$. Asimismo, el Jueves 15 de julio de 1593 el apuntador anotaba en el libro de horas lo siguiente:

...oy a terçia dieron posesión a el señor don García Pacheco de la canonjía que tenía el licenciado Bautista Velez y asi juro su merced luego antes de la misa mayor y hizo su residencia a la dicha missa mayor para el vestuario y luego me requirio el señor don Gil Pacheco que le diese por fe....

El canónigo venía cumpliendo con la asistencia a las horas mayores de manera que pedía que se le diese por ello como continuado en su vestuario "porque su señoría le habia hecho gracia para acauar su residencia" según tenía constatado, actuando como testigos Tomás Borja y el doctor Anaya ${ }^{35}$.

31 M.J. Lop Otín (2003) El Cabildo Catedralicio de Toledo en el siglo XV: Aspectos Institucionales y Sociológicos. Madrid: Fundación Ramón Areces, p. 88.

32 ACT, OF-909, f.256r.

33 M.J. Lop Otín (2003) op. cit., p. 309.

34 ACT, Libro segundo de horas de 1583.

35 Ibid. 
El canónigo nuevo estaba obligado a hacer la residencia anual continuada, que pretendía su formación, pues el año de residencia que se dio a la Iglesia "fue principalmente para que los que entraren en ella de nuevo se ynstruyan de lo que son obligados a facer" ${ }^{\text {"36 }}$. A ningún canónigo se le hacía ración, ni vestuario hasta que no hubiese estado en la iglesia un año entero sin faltar ningún día a una hora de las mayores. En caso contrario, que faltara algún día o no estuviese excusado por enfermo perdía el vestuario entero excepto si se le comisionaba para ir a algún negocio de la Iglesia ${ }^{37}$.

Después de hecha la primera residencia, el tiempo durante el que debía cumplirse la residencia anual era de noventa días "juntos o interpolados", si el prebendado era canónigo. Si el prebendado contaba con la categoría de dignidad, es decir, tenía una prebenda adscrita a un oficio honorífico y preeminente (deanato, arcedianato, etc.), la residencia se reducía a sesenta días, también seguidos o alternos ${ }^{38}$.

Si el prebendado, canónigo o dignidad, no completaba los noventa o sesenta días de rigor, respectivamente, perdía el vestuario entero. Las ausencias quedaban justificadas si el prebendado estaba excusado por enfermedad o se le hubiese comisionado para ir a tratar algún negocio, hecho nada infrecuente pues por su rango y responsabilidad en el gobierno de la Iglesia eran más habitualmente requeridos para atender los asuntos temporales. En estos casos eran tenidos por presentes y escritos, ganando su asignación como si hubiesen cumplido.

Los canónigos no ordenados in sacris, es decir, que no habían recibido órdenes mayores de presbítero, diácono y subdiácono, tenían derecho únicamente a la mitad del vestuario, siempre que hubiesen hecho la primera residencia anual y personal, servida por el mismo sin sustituto, y hasta que fueran ordenados de orden sacro. Este mandato lo era en virtud a una constitución dada el 2 de noviembre de $1435^{39}$, vigente en las constituciones dadas por el cardenal Tavera en 1539. Y es que la falta de ordenaciones entre los canónigos afectaba al servicio litúrgico, lo que ocasionaba gran daño a la Iglesia:

36 BCLM, MS-449, f.11v.

37 ACT, OF-909, f.202r.

38 En Toledo eran 14 las dignidades: el chantre o capiscol, el tesorero, el abad de santa Leocadia, el vicario del coro, el maestrescuela, el abad de San Vicente, el capellán mayor del coro y los arcedianos de Toledo, Talavera, Calatrava, Madrid, Guadalajara y Alcaraz

39 ACT, Arcayos (copia), vol.1, f.561r. 
...por lo qual la dicha Yglesia padeçe defecto de seruiçio, assi en el culto diuino açerca del altar como en los cabildos que no pueden en ellos estar y podrían dar buenos consejos a la dicha Iglesia si en los dichos cabildos fuesen interessentes ${ }^{40}$.

El criterio de reparto del vestuario para los canónigos no ordenados in sacris se tenía en cuenta también para las rentas del refitor, incumpliéndose en este caso según denunciaban los racioneros. Éstos se quejaban de que, a pesar de quedar prescrito en el Estatuto, sólo se guardaba con los racioneros, pero no con los canónigos que estando en circunstancias similares lo ganaban entero ${ }^{41}$.

Era el Cabildo el que en última instancia decidía sobre el reconocimiento de los días de residencia, otorgando gracias. Así, el 25 de septiembre de 1577 se reunían los canónigos para acordar si se daba el vestuario entero al licenciado Temino y a don Antonio Zapata, pues cuando habían empezado a hacer la primera residencia no estaban ordenados de Epístola y al no estarlo no ganaban más que la mitad del vestuario. Estudiadas las circunstancias, se decidía hacerles gracia de la otra mitad del tiempo que residieron hasta que se ordenaron, que fue dentro del año ${ }^{42}$. Estas y otras gracias no siempre contaron con el beneplácito de todos los miembros del Cabildo, siendo debatidas oportunamente en las sesiones capitulares.

Para el cómputo de la residencia debía tenerse en cuenta algunas licencias acostumbradas, como la concesión del denominado privilegio de San Miguel. Por este privilegio, según la constitución dada el 27 de septiembre de $1507^{43}$, si un canónigo o dignidad que hubiese residido el día de San Miguel muriese durante el período de residencia, con posibilidad de haberla completado si viviese, tendría derecho a ganar vestuario. El pago de la ganancia se realizaba en la persona de sus herederos: "para que con el dicho vestuario y lo otro que dexare pueda mejor descargar su conciencia en obras pias y satisfaçion de los criados" ${ }^{14}$. Sin embargo, estando el día de San Miguel, si cuando murió no hubiese

\footnotetext{
40 ACT, FS I, 2, f.46v.

$41 \quad$ ACT, X.10.A.3.5.

42 ACT, AC, vol.16, f.132r.

43 BCT, Arcayos (copia), f.15v. FS I, 2, f.49v-51v.

44 ACT, FS I, 2, f.51v.
} 
cumplido con los noventa días en caso de ser canónigo o sesenta días si fuese dignidad, ni tampoco le hubiese quedado tiempo para hacerlo, no se le asignaría ningún vestuario. Este privilegio se completaría con lo decidido en capítulo el 27 de septiembre de 1520. Ese día el Cabildo acordaba que en caso de producirse el fallecimiento fuera de la ciudad de Toledo, a la dignidad o al canónigo en cuestión se le contarían los días en que pudiera venir a Toledo desde donde falleciese. En concreto, el criterio era tomar un día por cada ocho leguas, considerándolos en la cuenta de los sesenta o noventa días de asistencia ${ }^{45}$.

El Cabildo acostumbraba a conceder el privilegio en no pocas ocasiones, justificando la asistencia necesaria a los canónigos comisionados para algún negocio en la Corte, estar haciendo información de beneficiados, etc. Así, el 25 de septiembre de 1577 se daba a Jerónimo Manrique que estaba en la Corte ${ }^{46}$. En el libro de horas 1593, el 29 de septiembre se decía que: "ganaron privilegio de San Miguel los señores tesorero Gaspar Yañez y Anaya", "perdiole el señor don Gil Pacheco porque falto a procesión y misa" ${ }^{47}$.

Por otra parte, la Constitución aprobada el 21 de octubre de $1488^{48}$ preveía la posibilidad de que los canónigos pudieran cumplir la residencia fuera de Toledo, al verse obligados a abandonarla por peste, otorgando el Cabildo licencia, siempre que tuvieran su casa en la ciudad y acostumbrasen a residir la mayor parte del año. En ese caso podrían continuarla en el lugar que se le asignase o en su defecto la que eligiesen a las horas previstas y siempre que fuese probado por fe del cura o del lugarteniente o del sacristán o notario de ese lugar.

Era el repartidor finalmente el encargado, teniendo en cuenta la norma de la corporación, de dar razón de los días de residencia que marcaban el reparto del vestuario. Por esta razón, al repartidor le correspondía tomar o escribir los nombres de todos los canónigos que estaban presentes, enfermos o comisionados por el Cabildo en el libro de los nombres. La información contenida en este libro era la utilizada por el receptor de vestuarios para ejecutar el reparto. Por ello, el libro previamente debía ser entregado a los mayordomos del Cabildo. Eran

\footnotetext{
45 BCT, Arcayos (copia), vol.2, f.566r.

46 ACT, AC, vol.16, f.132r.

$47 \quad$ ACT, Libro segundo de horas de 1593.

48 Texto publicado en M.J. Lop Otín (2003) op. cit., pp. 519-521.
} 
éstos los encargados de verificar las presencias, ver cuántos canónigos ganaban vestuario, la cantidad atribuible a cada uno de ellos y firmarlo con sus nombres ${ }^{49}$.

En la relación de los nombres de los canónigos se iban apuntando los que habían ganado vestuario (v), los que lo ganaban medio $\left(\mathrm{m}^{\circ} \mathrm{v}^{\circ}\right)$, los que habían ganado cabildo (c) y los ausentes (a) (ver Tabla 1).

Tabla 1: Relación de nombres de canónigos de $1534^{50}$

\begin{tabular}{|r|l|r|l|}
\hline & Nombre del canónigo & & Nombre del canónigo \\
\hline v.c & Bernardino Zapata Capiscol & v.c & Juan de Vargas capellán mayor \\
\hline v.c & García Manrique Tesorero & v.c & Pedro Juárez de Guzmán \\
\hline v.c & Diego López de Ayala vicario & v.c & Juan Ruiz Viejo \\
\hline v.c & Juan Álvarez de Toledo & v.c & Protonotario Juan Ruiz \\
\hline v.c & Bartolomé de Medina & v.c & Protonotario Alonso de Castro \\
\hline v.c & Bernardino de Alcaraz & v.c & Alonso de Castro \\
\hline v.c & Rodrigo de Acevedo & v & Alonso de Rojas arcediano de Segovia \\
\hline v.c & Rodrigo Ortiz & v.c & Jorge Maldonado \\
\hline v.c & Obispo Campo & v.c & Licenciado Francisco de Yepes \\
\hline v.c & Licenciado Alonso Mexía & v.c & Protonotario Antonio de León \\
\hline$m^{\text {o }}$ vo & Alonso de Rojas & v.c & Protonotario Miguel Díaz \\
\hline v.c & Juan de Luna & v.c & Protonotario Juan de Salazar \\
\hline v.c & Doctor Ortiz & v.c & Pedro de Yepes \\
\hline v.c & Francisco de Mora & v.c & Doctor Juan de Vergara \\
\hline v.c & Francisco de Silva & v.c & Pedro Gaitán de León \\
\hline v.c & Juan Ramos & v.c & Francisco Téllez \\
\hline v.c & Juan de Mariana & v.c & Pedro Fernández \\
\hline v.c & Cristóbal Navarro & v.c & Rodrigo Tenorio \\
\hline a & Obispo Francisco de Solís & v.c & Fernando Rodríguez \\
\hline v & Bernardino Zapata maestrescuela & & \\
\hline v.c & Pedro de la Peña abad de San Vicente & \\
\hline
\end{tabular}

\section{- Incidencias}

Las faltas a la residencia anual, en virtud a la cual los canónigos obtenían la gruesa de su canonjía, a pesar de lo escaso del requerimiento, no eran menos frecuentes que las evidenciadas para el

\footnotetext{
49 ACT, OF-909, f.205r.
}

50 ACT, OF-1454, f.40v. 
refitor. Al igual que en este último caso, estas faltas podían estar o no justificadas, hablándose de privilegios 0 ausencias de irresidencia, respectivamente.

El vestuario se perdía por no cumplir con los sesenta o noventa días de residencia que exigía la norma interna, declarándose el canónigo ausente. Sin embargo, no era infrecuente que los canónigos intentaran que se les reconociera dicha residencia, como lo hacían con las del refitor:

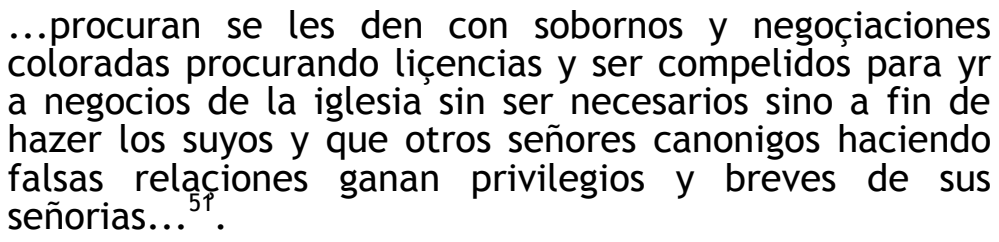

Así había canónigos que ausentados pedían gracia general y particular a cada canónigo, en contra de los estatutos antiguos, de las constituciones y de las bulas apostólicas, y se les concedía. Para evitar esto, el 28 de junio de 1531 se aprueba el estatuto por el "que ninguno pueda pedir vestuario perdido iurada con pena de un año", estatuto presente en las constituciones dadas por el cardenal Tavera en $1539^{52}$. El estatuto negaba gracia a los que pedían el vestuario, tanto para ellos como para otros, penándoles con la ganancia de un año "que no gane cosa alguna en esta Sancta Iglesia, ni entre en ella a ganar"; y con medio año al que diese o hiciese la gracia. A pesar de su aprobación, no todos aceptaron la resolución, pues no lo otorgó ni juró Diego López de Ayala ni lo juraron Juan Álvarez de Toledo y Rodrigo Ortiz.

Al Cabildo tampoco le fue fácil evitar las discrepancias con algunos canónigos por el cómputo de los días para la residencia, sobre todo, en cuestiones concretas como destierros, estudios o comisiones. En el caso de destierro, la Constitución de los desterrados de 15 de abril de 1506 reconocía que siempre que no fuera por culpa del interesado o por cosa concerniente a la Iglesia el desterrado ganaría toda su prebenda junto a las distribuciones cotidianas, salvo maitines, en todo el tiempo y durante todo el llamamiento o destierro. En 1546 se mandaba que al así desterrado se le escribiera en el coro todas las horas salvo maitines hasta

\footnotetext{
51 ACT, AC, vol.15, f. 324v-325r.

52 ACT, FS I, 2, f.53v-54r.
} 
que fuera sentenciado, en tal caso el Cabildo luego determinaría si se lo debían haber o no $^{53}$.

El canónigo Quiroga reclamaba su vestuario de 1545, al haber hecho su residencia continua desde el día de San Miguel hasta el 2 de noviembre de 1545, cuando le negaban la entrada en la iglesia por excomulgado, a color de ciertas censuras contra él, fulminadas por el auditor de la Cámara Apostólica hasta que mostrase absolución, lo que le obligaría a ir a Roma personalmente, de donde vendría libre y sin culpa. Por lo que en virtud a las censuras declaradas y presentadas, solicitaba ser dado por presente hasta la víspera de San Miguel del año de 1546, y en consecuencia reclamaba el pago del vestuario y refitor de ese año y todo lo que ganaron los canónigos que en ese tiempo estuvieron presentes y residieron en la iglesia ${ }^{54}$.

Eran privilegiados los que gozaban de licencia para no residir por alguna de las circunstancias previstas en la norma: estudio general, estancia en Corte de Roma, ocupación en litigios y causas, estar al servicio de príncipes o poderosos, y por estudios o enfermedad. Por esta razón para cada canónigo privilegiado, autorizado a no residir conforme a derecho, se le apartaban 60 florines de oro de cuño de Aragón solum et dum taxat, aunque los frutos de los vestuarios valieran mucho o poco. Este derecho, ordenado y confirmado por Bula apostólica, autorizaba al canónigo a no llevar por razón de su vestuario más de los consabidos 60 florines (15.900 mrs, a razón de 265 maravedís por florín.) Estos se apartaban de lo que importaban los vestuarios antes del reparto, haciéndose descargo de ellos en la cuenta, tal y como figura en el siguiente asiento de 1530, en el que se hace descargo de 60 florines para un privilegiado:

"Yten de un privilegiado que es Benito Grentil quinze myll novecientos mrs $X V$ U DCCCC

Las ausencias de los canónigos no dados por privilegiados eran repartidas entre los canónigos asistentes a determinados puntos, como queda reflejado en el siguiente asiento de 1530:

\footnotetext{
53 ACT, A.9.I.1.1., f.2v.

54 Ibid., f.4r.

55 ACT, OF-1452, f.9v.
} 
"Yten se sacan de çinco ausencias que hubo este año a sesenta florines cada una. Setenta e nueve myll e quinientos mrs. que fueron Juan Antonio de la Mota, el señor deán, don Bartolomé de la Cueva, don García Manrrique e don Diego de Avellaneda "56

No ganaban la residencia para vestuarios los canónigos que iban a estudiar a Salamanca o a cualquier otro estudio universal, salvo el tercio de pan y sal del refitor, en los términos prescritos según lo mandado en la Constitución dada el 11 de octubre de $1485^{57}$.

\section{LA ADJUDICACIÓN DE LOS VESTUARIOS}

En principio parece que la adjudicación del vestuario se hacía con una distribución equitativa de lo obtenido por los diezmos de pan y vino entre los canónigos que lo hubiesen ganado. Para ello, tras la suma de los remates del pan, se hacían las valoraciones agregando éstos al importe de las copias del vino. Luego se sustraían los gastos (salarios del receptor, del secretario, del pertiguero, etc.; costas de enviar y poner cédulas, gastos de libros, etc.), importes a distribuir por separado (ausencias, privilegios, cabildos, lo de Hita y los aliceres ${ }^{58}$ ) y el subsidio, que iba a las arcas reales en virtud al prorrateo de dicho importe entre las rentas eclesiásticas de la diócesis. Lo que se obtenía después de estas deducciones iba destinado a la distribución a partes iguales entre los canónigos.

En 1535 importaron los vestuarios 6.694 .600 maravedís y 8 dineros a repartir entre los canónigos que hubiesen ganado vestuario ese año, 37 canónigos.

56 Ibid., f.9v.

57 ACT, OF-909, f.254v.

58 Los aliceres, según los contratos de arrendamiento, era el medio diezmo de más del precio de remate, "otrosi que de toda la cantidad del precio de qualquier renta ansi del pan como de maravedis paguen los dichos arrendadores alizeres que es medio diezmo de mas del precio en que se rematare la tal renta". ACT, OF-1454, f.2r. 
"Por manera que sacadas las dichas seteçientas y çinqueta y tres myll e seteçientos y setenta y tres maravedis que montaron los dichos descargos de los dichos siete quentos e quatroçientos e quarenta e ocho myll treçientos setenta e tres maravedies y ocho dineros que monto el dicho cargo restan que se han de repartir entre los señores canonigos que ganaron vestuarios este año de quinientos e treynta e çinco anos. Seys quentos y seysçientos y noventa y quatro myll seiscientos y ocho dineros

Hanse de Repartir

VI q $D C X C I I I I^{\circ} \cup D C: V I I I d^{\circ}$

En total importó cada vestuario, sin considerar los aliceres, lo del préstamo de Hita, las ausencias y los cabildos, $176.173 \mathrm{mrs}$ y $7 \mathrm{~d}^{\circ}$. Separado de esto y teniendo en cuenta el cumplimiento prescrito para ello recibiría cada canónigo: $8.894 \mathrm{mrs}$ y $5 \mathrm{~d}^{\circ}$ de los aliceres (a repartir $337.991 \mathrm{mrs}$ ); $8.456 \mathrm{mrs}$ del préstamo de Hita para los canónigos que lo ganaron entero porque hubo otros que no (a repartir $284.623 \mathrm{mrs}$ ); 1.000 mrs de los cabildos (a repartir $34.000 \mathrm{mrs}$ ); $181 \mathrm{mrs}$ de las ausencias de Todos los Santos al que lo ganó entero (a repartir $5.300 \mathrm{mrs}$ ); $154 \mathrm{mrs}$ y $5 \mathrm{~d}^{\circ}$ de las ausencias de Resurrección (a repartir $5.300 \mathrm{mrs}$ ); y $169 \mathrm{mrs}$ y $3 \mathrm{~d}^{\circ}$ de las ausencias de la fiesta de la Asunción (a repartir 5.300 mrs).

La forma de adjudicar el vestuario a los canónigos experimentaría ciertas modificaciones a partir de 1549. Este año no se consiguieron rematar las rentas de los diferentes arciprestazgos. El día 5 de diciembre, estando en los estrados de la claustra, donde se acostumbran y solían hacer las rentas de vestuarios, para rematar las de 1549 con las condiciones que se habían escrito y que fueron leídas y publicadas de verbo ad verbum por voz de pertiguero ${ }^{60}$, no se consiguió rematar la de ningún arciprestazgo, "no hubo quien fablase sobre ello".

Los libros de vestuarios de ese año de 1549 advierten de la promulgación de una pragmática dada por el rey Carlos que afectaba al arrendamiento de las rentas eclesiásticas y otras rentas de los reinos. En ella se "dispone acerca de los que compran pan para revender en la qual se declaro en los arrendamientos de las rentas eclesiásticas y de otros que se hacen en estos reynos" ${ }^{\prime 1}$. La pragmática intentaba remediar la

\footnotetext{
59 ACT, OF-1452, f.41v.

60 ACT, OF-1454, f.240r.

61 ACT, OF-1458, f.1r.
} 
reventa, pues muchas personas habían tomado este oficio como principal y compraban pan, trigo, cebada y centeno para revenderlo, lo que disparaba los precios. Aunque se habían dado provisiones para remediarlo no habían sido suficientes y los precios continuaban al alza. Por eso se prohibía la reventa bajo pena de perder todo el pan que se comprase ${ }^{62}$.

En agosto de 1548 se había mandado que:

...para provisión de las alhónigas ${ }^{63}$ y aholíes ${ }^{64}$, y depósito de pan, y panaderías, y plazas y las villas y lugares destos nuestros Reynos y Señoríos, cada uno de los dichos pueblos puedan tomar a los arrendadores de pan la mitad del trigo y cebada, centeno y avena, que en cada uno dellos hobiere de las dichas rentas, pagando por ellos a los arrendadores, que lo hobieren arrendado, el precio á como les saliere (Ley 21, tít.11, lib.5.R.) ${ }^{65}$.

La dificultad que supuso la norma impuesta en el remate de las rentas de ese año obligaría a cambiar la forma de hacer negocio con los vestuarios y la manera de adjudicación. Para ello el Cabildo resolvió comisionar a varios canónigos, en concreto, a Diego López de Ayala, Francisco de Silva, Bernardino de Alcaraz, Gaspar de Aponte, al protonotario Antonio de León, al Prior Cebrián, al Licenciado Quiroga y al bachiller Juan Delgado. Éstos debían, por orden del Cabildo, buscar el mejor medio para que fuese posible, con la norma vigente, beneficiar las rentas.

Por virtud de la dicha comisión, los canónigos reunidos en diversas ocasiones y una vez que hubieron deliberado y discutido sobre la solución:

...determinaron que visto el impedimento de la dicha prematica no se puedan arrendar las rentas que de los medios que entre ellos se han tratado y platicado que fueron diversos, el mejor parecía que se echasen cuatro personas por todos los arciprestazgos del arzobispado y que estos trajesen el valor verdadero del precio del trigo

62 Novísima Recopilación, Libro VII, Título XIX, Ley III.

63 Es la casa diputada para que los forasteros que vienen de la comarca a vender trigo a la ciudad lo metan allí; y este nombre tiene en Toledo esta casa. S. Covarrubias Orozco (1611) op. cit. Vox alhondiga. (1611) op. cit. Vox alholí.

64 El granero público donde se recoge el trigo y la cebada. S. Covarrubias Orozco

65 Los códigos españoles concordados y anotados, T.8, Madrid, 1850, p. 473. 
y cebada y centeno de todos los lugares principales de cada arciprestazgo ${ }^{66}$.

\section{- El testimonio de los precios}

Los precios estimados en los puntos de recaudación orientarían el remate y servirían para la valoración del vestuario, utilizándose también para las rentas decimales de la mesa capitular. Para su ejecución se comisionaba a personas, normalmente cuatro, encargadas de hacer las averiguaciones correspondientes en los diferentes lugares ${ }^{67}$, de los que les hacía relación numerada en una memoria: "los correos que van para los vestuarios y llevan la orden siguiente" o "los correos que van por los testimonios para los vestuarios llevan la orden siguiente"68. Los peones visitaban los lugares relacionados "comenzando desde el primero por orden y así sucesivamente hasta venir al postrero"69. Cuando llegaban al lugar sondeaban los precios "muy secretamente"70 para conseguir los valores "verdaderos" del pan, trigo, cebada y centeno ${ }^{71}$, acudiendo a "personas fidedignas que digan la verdad"72. Para la valoración de las rentas de 1550 el Cabildo mandaría tomar los precios a Gonzalo Muñoz, Jorge Manzareno, Cristóbal Gómez y Antón Gómez ${ }^{73}$.

Con la información que les proporcionaban en los diferentes lugares que visitaban, los diputados elaboraban una memoria, donde iban haciendo recopilación del nombre del lugar, de lo que valía la fanega de trigo, la cebada y el centeno ${ }^{74}$, separadamente: "los lugares que cada uno dellos anduvo y los precios del pan de cada lugar van por su orden conforme a la orden del año pasado y es la manera que sigue"75. Tras la recopilación, los averiguadores abandonaban el lugar no sin antes hacer

66 ACT, OF-1458, f.1r-1v.

67 Otra forma de proceder para averiguar los precios de los lugares era encomendando a los curas en sus parroquias averiguar en público o en secreto, tomando el testimonio de los labradores sobre los precios.

68 ACT, OF-1459, f.1r.

69 ACT, OF-1458, f. $4 \mathrm{v}$

70 Ibid., f.4v.

71 Idem, f.1r.

72 Idem, f.4v.

73 Idem, f.25r.

74 Idem, f.4v.

75 Idem, f.52r. 
pregonar la cédula que llevaban del secretario, donde se informaba de la fecha del arrendamiento. En esto, se advertía a los averiguadores que antes de hacer pregonar la cédula debían asegurarse de tener el valor del pan. Acabado el pregón, se procedía por mandato del Cabildo a colocar la cédula en la puerta de la iglesia del lugar donde se pregonase. El Cabildo podía ordenar, generalmente en el mes de octubre, que se enviasen las cédulas de los vestuarios a los lugares de las rentas referidas. De esta situación dan testimonio las actas capitulares, cuando avanzado el mes de octubre se ordenaba a los receptores que enviasen las cédulas de los vestuarios "como es costumbre hacerse"76.

La valoración de los vestuarios era imprescindible para orientarse en las pujas y que las rentas adquirieran un precio ventajoso en el momento en que se efectuara el remate. Éste era un medio de tantear el remate y evitar pérdidas. En definitiva, constituía la base para impedir también que se remataran rentas por debajo de su valor.

Hubo años en que la valoración no se haría tomando los precios por testimonio sino de acuerdo a la pragmática. Así, el 10 de octubre de 1591 se mandaba que todo el pan de los vestuarios se valorase a la pragmática y no se enviasen por testimonio ${ }^{77}$. Mientras que en los casos en los que el pan no llegaba a la $\operatorname{tasa}^{78}$ o no lo valiese, el Cabildo mandaba el 8 de octubre de 1592 que se enviasen a tomar el testimonio del precio para hacer las suertes ${ }^{79}$. El 12 de octubre decidía que se valorase todo el pan de los vestuarios a la pragmática y lo que no lo valía se sacase para gastos, siendo lo que valiese menos por cuenta del Cabildo. Al parecer ese año no se llegó a la tasa en algunos lugares como en la Vicaria y Las Cuadrillas y en Alcaraz.

\section{- La valoración de los vestuarios}

Una vez conseguidos los precios se hacían las valoraciones. De las rentas de pan, trigo, cebada y centeno "tasado a los precios que se

76 ACT, AC, vol.5, f.19r. El mismo proceder se seguía para los diezmos del arzobispo. De ello da cumplida cuenta M. Gutiérrez García-Brazales (1982) "La decimación en el arzobispado de Toledo (1508-1837)", Toletvm, 13, p. 238.

77 ACT, AC, vol.20, f.179v.

78 Por Real cédula de 29 de agosto de 1566 se aumentó el precio de la cebada a 180 mrs. La pragmática de 8 de octubre de 1571 por la cual se prohíbe vender el trigo en grano no excediendo al precio de 11 reales por fanega (ley 4, tít.25, lib.5R).

79 ACT, AC, vol.20, f.270r. 
contienen en el valoramiento que esta escrito (...) hojas antes de esta en este libro". En caso de que en un lugar se recogiesen varios precios, el pan se tasaba a un precio medio simple. Así, el 6 de noviembre de 1587 mandaba el Cabildo que "en el lugar do habia dos precios varios juntados ambos la mitad y por donde había tres el tercio"80, y se asentasen en el pliego. También se tomaban diferentes medidas para determinar un precio cuando el grano era de diferente condición. El 20 de noviembre de 1572 se mandaba que en los lugares de La Mancha donde en los testimonios del pan viniese el precio del candeal ${ }^{81}$, proxy y trigo común, el racionero Alonso Sánchez asentase como precio de estos lugares lo siguiente: donde se tiene duda, 7 reales; donde fuese centeno y no llegara a 5 reales, lo pusiera como viniese; y en donde viniese a más de 5 reales, lo pusiera a 5 reales $^{82}$.

Para hacer más fácil y rápida la valoración del pan de los vestuarios se contaba con unas tablas de equivalencias previamente elaboradas. En estas tablas se hacía recopilatorio de diferentes importes referidos a posibles precios y determinadas medidas para cada uno de esos posibles precios. Estas medidas registradas en las tablas aparecían dispuestas en unidades que iban de las de mayor capacidad hasta las de menor. Para cada una de ellas se incorporaba la valoración tomando cada uno de los precios de referencia. A modo de ejemplo, en el Libro manual se contienen "...escritas en las siete hojas siguientes catorze tablas de preçios de fanegas para el valoramiento de los vistuarios para escusar trabaxo y hazerse con mas façilidad son XXV precios" ${ }^{83}$.

En la valoración de los vestuarios no se consideraba la parte del arciprestazgo de Hita y Brihuega, sumándose el pan al resto de las copias del vino en dinero, que solían llegar en noviembre procedentes del escribano mayor de rentas del arzobispado, al que se le solía gratificar con unos pares de gallinas por mandarlas pronto. Al valor de las rentas que contablemente se registraban en el cargo, tal y como señalamos más arriba, había que sustraerle las ausencias de los canónigos privilegiados, lo que se ganaba a los cabildos, el importe para el subsidio y excusado del fruto de ese año, los gastos de la cobranza, las copias, correos y salarios de las averiguaciones del valor de los precios del pan y de hacer las

\footnotetext{
80 ACT, OF-1485, f.204r.

81 Trigo aristado, con la espiga cuadrada, recta, espiguillas cortas y granos ovales, obtusos y opacos, que daba una harina blanca de calidad superior.

82 ACT, AC, vol.15, f.332v.

83 ACT, OF-909, f.210r.
} 
suertes de vestuarios del año siguiente y otros gastos que solían sobrevenir tocantes a los vestuarios. Lo que quedaba en pan y dineros se repartía entre los canónigos que habían ganado vestuario ese año.

A veces desde el Cabildo se disponía que parte del pan que se sacaba para los gastos de los vestuarios se diera para sembrar. Así, el 19 de octubre de 1591 se mandaba a la contaduría que diera orden de que el pan que se sacase para los gastos de los vestuarios se diera para sembrar y que el licenciado Gomara guardara el orden que se diese en la contaduría para repartirlo ${ }^{84}$.

Para efectuar el reparto entre los canónigos, lógicamente debía conocerse el número de los que habían ganado vestuario ese año de septiembre a septiembre, pues la renta a rematar en diciembre de ese año se ganaba con la residencia de septiembre del año anterior a septiembre del presente año. En virtud al número de canónigos se hacían las suertes, de manera que si treinta y siete eran los canónigos residentes, treinta y siete eran las suertes. Lo que quedaba para repartir de la valoración del pan y del dinero de las copias se dividía entre el número de suertes, calculando el importe del vestuario completo de ese año para cada canónigo.

El modo de proceder con suertes se prolongó al año siguiente de 1550, según se decidió en capítulo el 20 de diciembre, cuando atento a que no salieron arrendadores, echaron las suertes de sus vestuarios conforme al año pasado y con las mismas condiciones ${ }^{85}$, al igual que en años sucesivos.

\section{- La forma de hacer las suertes}

Antes del remate de los diezmos, que se producía en diciembre, debían hacerse y echarse las suertes, según se señala en las condiciones de remate y arrendamiento. Las suertes se hacían tomando en cuenta el valor del vestuario de ese año, haciéndose, como ya hemos señalado, tantas suertes como canónigos habían ganado vestuario.

Las suertes debían hacerse valorando el pan y los maravedís de las copias de vestuarios de los veinticinco arciprestazgos, de manera que el pan sería "apreçiado en cada parte conforme a el testimonio que

84 ACT, AC, vol.20, f.182r.

85 ACT, AC, vol.8, f.194r. 
de alli vino"86. Para hacer las suertes se hacían lotes de rentas, dando o quitando hasta que estuvieran igualados (ver Tabla 2 con 5). En caso de llegar a alguna diferencia entre ellos, ésta servía como complemento para pagar el subsidio y otros gastos aparejados a los vestuarios ${ }^{87}$. Las suertes eran igualadas con una destreza admirable.

En 1556 se harían 37 suertes, siendo el valor del vestuario $354.200 \mathrm{mrs}$. Cuando el valor de la suerte superaba el importe del vestuario, la diferencia iba al arca de vestuarios (ver Tabla 2), que permanecía custodiada en la Tesorería bajo la responsabilidad de la dignidad de Tesorero, estando uno de los canónigos nombrados a su cuidado.

Tabla 2: Detalle de la suerte 10 de $1556^{88}$

\begin{tabular}{|c|c|c|c|c|c|}
\hline $\begin{array}{l}\text { Núm. } \\
\text { suerte }\end{array}$ & \multicolumn{2}{|l|}{ Lugares } & \multirow{2}{*}{$\begin{array}{l}\text { Fanegas de pan } \\
800 \mathrm{f} .\end{array}$} & \multirow{2}{*}{$\begin{array}{c}\text { Reales/par } \\
\text { fanegas }\end{array}$} & \multirow{2}{*}{$\begin{array}{r}\begin{array}{c}\text { Valoración } \\
\text { (maravedís) }\end{array} \\
210.800\end{array}$} \\
\hline \multirow{9}{*}{10} & \multirow[t]{2}{*}{ La Guardia } & Pan de Tembleque con Borregos & & & \\
\hline & & Dinero de este lugar & & & 7.320: $1 \mathrm{~d}$. \\
\hline & \multirow[t]{4}{*}{ Illescas } & Cabañas de la Sagra & 110 f. 7 c. y 2 q. & 16,5 & 31.027: $9 \mathrm{~d}$. \\
\hline & & Dinero de este lugar & & & $112: 5 \mathrm{~d}$. \\
\hline & & Villaluenga & 69 f. 6 c. y 3 q. & 15,5 & 18.326: $5 \mathrm{~d}$. \\
\hline & & Dinero de este lugar & & & 3.618: $4 \mathrm{~d}$. \\
\hline & Calatrava & $\begin{array}{l}\text { Terzuelos de Alcolea, Picón y } \\
\text { Puertollano }\end{array}$ & & & 83.344: $2 \mathrm{~d}$. \\
\hline & \multicolumn{4}{|l|}{ Total } & 354.549: $6 \mathrm{~d}$. \\
\hline & \multicolumn{4}{|c|}{ "Ha de volver esta suerte al arca" } & 349: $6 \mathrm{~d}$. \\
\hline
\end{tabular}

Por el contrario, si el valor de la suerte resultaba inferior al importe del vestuario, la diferencia se "habia de haber del arca" de vestuarios (ver Tabla 3).

También iban a parar al arca los descuentos que se le aplicaban al canónigo moroso por deudas contraídas con el Cabildo y el dinero procedente de las ausencias no ganadas (ver Tabla 4).

86 ACT, OF-1458, f.23r-30v.

87 ACT, AC, vol.8, f.87r.

${ }^{88}$ ACT, OF-1459, f.24v. 
Tabla 3: Detalle de la suerte 1 de $1556^{89}$

\begin{tabular}{|c|c|c|c|c|c|}
\hline Núm. & \multicolumn{2}{|l|}{ Lugares } & Fanegas de pan & Reales/par & $\begin{array}{l}\text { Valoración } \\
\text { (marayedís) }\end{array}$ \\
\hline \multirow{6}{*}{1} & \multirow[t]{4}{*}{ Alcaraz } & \multirow{2}{*}{$\begin{array}{l}\text { Santa María y la Trinidad de Alcaraz, } \\
\text { Lezuza, Susaña, Valazote, Reolid, } \\
\text { Villapalacios, La Puebla con Matilla, } \\
\text { el Pozo que dicen Villaverde, Cotillas } \\
\text { Riopar, Paterna, Bogarra Ayna, El } \\
\text { Ballestero y Vianos }\end{array}$} & $\begin{array}{l}241 \text { f. y } 10 \text { c. } \\
656 \text { f. } 7 \text { c. y } 2 \text { q }^{\text {o. }}\end{array}$ & $\begin{array}{c}16,5 \\
17\end{array}$ & $\begin{aligned} 67.834: 2 \mathrm{~d} \\
189.762: 2 \mathrm{~d}\end{aligned}$ \\
\hline & & & 898 f. 5 c. y $2 q^{\circ}$. & & 257.596: $4 \mathrm{~d}$. \\
\hline & & $\begin{array}{l}\text { Dinero de estos lugares y parroquias } \\
\text { más los de San Ignacio y San Miguel } \\
\text { y San Pedro de Alcaraz }\end{array}$ & & & 66.044: $9 \mathrm{~d}$. \\
\hline & & $\begin{array}{l}\text { Terzuelos de Santa Cruz y La Puebla } \\
\text { de Montiel }\end{array}$ & & & 29.078: $5 \mathrm{~d}$. \\
\hline & \multicolumn{4}{|l|}{ Total } & $352.719: 8 \mathrm{~d}$. \\
\hline & \multicolumn{4}{|c|}{ "Ha de auer esta suerte en el arca " } & 1.480: $2 \mathrm{~d}$ \\
\hline
\end{tabular}

Tabla 4: Detalle de la suerte 2 de $1556^{90}$

\begin{tabular}{|c|c|c|c|c|c|}
\hline $\begin{array}{l}\text { Núm. } \\
\text { suerte }\end{array}$ & \multicolumn{2}{|l|}{ Lugares } & Fanegas de pan & $\begin{array}{l}\text { Reales/par } \\
\text { fanegas }\end{array}$ & $\begin{array}{l}\text { Valoración } \\
\text { (maravedís) }\end{array}$ \\
\hline \multirow{9}{*}{2} & \multirow[t]{3}{*}{ Alcaraz } & San Ignacio y San Pedro & 120 f. 3 c. y $2 q^{\circ}$. & 16,5 & 33.739: $4 \mathrm{~d}$. \\
\hline & & $\begin{array}{l}\text { Munera, Villarobledo, Villalgordo } \\
\text { con el Corralejo }\end{array}$ & 695 f. y 2 c. & 17 & 200.903: $1 \mathrm{~d}$. \\
\hline & & \multicolumn{3}{|c|}{ Dinero de Munera, Villarobledo con el Corralero } & 44.555: $7 \mathrm{~d}$. \\
\hline & Illescas & Pantoja & 107 f. y $5 \mathrm{c}$. & 16,5 & 30.080: $3 \mathrm{~d}$. \\
\hline & Alcaraz & \multicolumn{3}{|c|}{$\begin{array}{l}\text { Terzuelos de pan y vino de Fuenllana y de los lugares de la } \\
\text { encomienda mayor }\end{array}$} & 47.375: $4 \mathrm{~d}$. \\
\hline & \multicolumn{4}{|l|}{ Total } & 356.653: $9 \mathrm{~d}$. \\
\hline & \multicolumn{4}{|c|}{ "Ha de volver esta suerte al arca" } & 2.453: $9 \mathrm{~d}$. \\
\hline & \multicolumn{4}{|c|}{ "Yten de las ausencias" } & 981 \\
\hline & & & & & 3.434: $9 \mathrm{~d}$. \\
\hline
\end{tabular}

Por el contrario, se tomaba del arca el importe necesario para cubrir el vestuario completo, teniendo en cuenta lo que se ganaba o se perdía de las ausencias (ver Tabla 5).

89 Ibid., f.23r.

90 Idem, f.23r. 
Tabla 5: Detalle de la suerte 11 de $1556^{91}$

\begin{tabular}{|c|c|c|c|c|c|}
\hline $\begin{array}{l}\text { Núm. } \\
\text { suerte }\end{array}$ & \multicolumn{2}{|l|}{ Lugares } & Fanegas de pan & $\begin{array}{l}\text { Reales/par } \\
\text { fanegas }\end{array}$ & $\begin{array}{l}\text { Valoración } \\
\text { (maravedís) }\end{array}$ \\
\hline \multirow{8}{*}{11} & \multirow[t]{3}{*}{ La Guardia } & Pan de Tembleque con Borregos & 472 f. 4 c. y q ${ }^{\circ}$. & & $\begin{array}{r}\text { 124.464: } 2 \mathrm{~d} . \\
\text { "porque la } \\
\text { resta llevo la } \\
\text { suerte } 10 "\end{array}$ \\
\hline & & $\begin{array}{l}\text { La Torre y Bel, Huerta de } \\
\text { Valdecarábanos }\end{array}$ & 355 f. 3 c. y $3 q^{\circ}$ & 15 & 90.605: $7 \mathrm{~d}$. \\
\hline & & Dinero de estos lugares & & & 5.231: $8 \mathrm{~d}$. \\
\hline & \multirow[t]{2}{*}{ Illescas } & $\begin{array}{l}\text { Moratalaz, Yeles, Esquivias, } \\
\text { Yuncler y Cedillo }\end{array}$ & 181 f. 3 c. y $1 q^{\circ}$ & 15,5 & 47.785: $7 \mathrm{~d}$. \\
\hline & & \multicolumn{3}{|l|}{ Dinero de estos lugares } & 16.838 \\
\hline & Calatrava & \multicolumn{3}{|c|}{ Terzuelos de Malagón y Argamasilla } & 68.135: $2 \mathrm{~d}$. \\
\hline & \multicolumn{4}{|l|}{ Total } & 353.060: $6 \mathrm{~d}$. \\
\hline & \multicolumn{4}{|c|}{$\begin{array}{l}\text { Ha de haber en el arca } 1.139 \mathrm{mrs} \text { y } 4 \mathrm{~d} \text {. "descontando de los quales C VII } \\
\text { que perdio de las ausencias resta que le deue el arca IUXXXII: IVd". }\end{array}$} & \\
\hline
\end{tabular}

\section{- La forma de echar las suertes}

Una vez igualadas, las suertes eran registradas por el notario del Cabildo, pasándose seguidamente a la adjudicación de los lotes, que se acostumbró a hacer por sorteo entre los canónigos ${ }^{92}$, era lo que se conocía como echar las suertes. El sorteo ${ }^{93}$ evitaba las susceptibilidades que pudieran generarse entre los canónigos por la adjudicación de las rentas $^{94}$.

Las suertes se echaban ante el notario y el secretario del Cabildo. Para el sorteo se tomaban dos cántaros o jarras, en uno se echaban unas hojas o cédulas con los nombres de los canónigos que hubiesen ganado vestuario ese año; y en el otro recipiente, otras cédulas con las

91 Idem, f.25r.

92 Estas diferencias se aprecian en los libros de reparto de 1529-1548 (ACT, OF1452) y el de 1549-1554 (ACT, OF-1458).

93 Esta forma de proceder era similar a la que se practicaba para los diezmos del cabildo en Sevilla. En esta ocasión se repartía entre los prebendados ciertos números para el sorteo (dos números para las dignidades, un número para los canónigos y un número por cada dos para los racioneros y medioracioneros). J. Hernández y R. Donoso (2008) "El sistema administrativo y contable de los diezmos de la diócesis de Sevilla en el siglo XVII", Nuevos estudios sobre Historia de la Contabilidad, Burgos, p. 283.

94 Recurrente para otras decisiones de diversa índole (elecciones de oficiales, comisiones, etc.), estaba presente ya en el Antiguo Testamento, y permitía tomar decisiones bajo la dirección divina, confiando en que Dios se impondría a las suertes ocupándose de que se eligiera su voluntad. Lv. 16:8; Núm. 26:55; Pr. 16:33. 
suertes. Seguidamente, alguien, que podía ser uno de los clerizones más jóvenes del coro, iba sacando de uno y otro cántaro el nombre con las suertes. A medida que se iban nombrando las suertes se procedería a extraer del cántaro el papel con el nombre del canónigo. De esta manera se iban sacando las órdenes, haciéndosele entrega al canónigo de la suerte que le cupiese y haciéndose registro de las mismas, escribiendo en un papel el nombre del canónigo con el número de la canonjía y la suerte que le cabía (ver Tabla 6).

Se repartio todo el pan y mrs de las copias de vistuarios apreciado en cada parte conforme a el testimonio que da alli vino y se cargaron las dichas çedulas en una jarra dorada y los nombres de los señores que ganaron vistuarios el dicho año de MDL en otra y se sacaron en cabildo por dos clerizones los mas pequeños que avia en el coro cada uno sacado de su jarra y salieron las dichas çedulas. ${ }^{95}$

Tabla 6: Detalle de la adjudicación de las suertes $1556^{96}$

\begin{tabular}{|c|l||c|l|}
\hline $\begin{array}{c}\text { Número } \\
\text { de suerte }\end{array}$ & Nombre del canónigo & $\begin{array}{c}\text { Número } \\
\text { de suerte }\end{array}$ & Nombre del canónigo \\
\hline 1 & García Manrique & 20 & Doctor Delgado \\
\hline 2 & El licenciado Quiroga & 21 & Pedro de Ribadeneira \\
\hline 3 & Antonio del Águila & 23 & Diego Ortiz \\
\hline 4 & Juan de Barrionuevo & 24 & Francisco de Pomara \\
\hline 5 & Capiscol y canónigo & 25 & Antonio de León \\
\hline 6 & García de Tablares & 26 & Licenciado Salazar \\
\hline 7 & Don Ramiro & 27 & Fernando de Bazán \\
\hline 8 & Licenciado Valdivieso & 28 & Doctor Herrera \\
\hline 9 & Rodrigo Tenorio & 29 & Doctor Vergara \\
\hline 10 & El Prior Cebrián & 30 & Alonso Ruiz \\
\hline 11 & Esteban de Valera & 31 & Capellán mayor Rodrigo Zapata \\
\hline 12 & Doctor Peralta & 32 & - \\
\hline 13 & Sebastián de Sosa & 33 & Miguel Díaz \\
\hline 14 & Rodrigo de Ávalos & 34 & Diego de Guzmán \\
\hline 15 & Bernardino de Alcaraz & 35 & Leonardo Ortiz \\
\hline 16 & Abad de Santa Leocadia & 36 & - \\
\hline 17 & Abad de San Vicente & 37 & Francisco Tellez \\
\hline 18 & Alonso de Rojas & \\
\hline 19 & Antonio de Castro & \\
\hline & & & \\
\hline
\end{tabular}

95 ACT, OF-1458, f. $35 \mathrm{r}$

96 ACT, OF-1459, f.23r-30v. 
En el sorteo debían hallarse el notario y el secretario del Cabildo, soliendo este último tomar un ayudante que se encargaba de ir escribiendo las suertes, que posteriormente se acostumbraban a encuadernar en un libro. Todos estos personajes y los clerizones eran convenientemente remunerados por su trabajo.

La adjudicación de las suertes se haría respetando el resultado del sorteo, dándose solución a los contratiempos en cabildo. En caso de que el canónigo al que cabía la suerte falleciese, el Cabildo podía concedérsela a sus herederos, haciéndolo efectivo una vez se demostraba que el fallecido no tenía contraídas deudas. El 23 de noviembre de 1576 mandaba que se diera la suerte del vestuario del canónigo Tablares a su heredero el señor Domingo González de Mendoza ${ }^{97}$.

\section{LA GESTIÓN DEL VESTUARIO}

\section{- El recudimiento de cobranza}

Tras la adjudicación de las suertes el Cabildo otorgaba a cada canónigo el recudimiento para su cobranza ${ }^{98}$, antes se comprobaba que no tenía contraída deuda, pues no era infrecuente que los canónigos mantuviesen alguna con la iglesia: con la mesa del refitor, por mantener heredades en renta o censo, como arrendadores principales o fiadores, así como por tomar en arrendamiento los vestuarios y por alcances contra ellos de recibir y recaudar en nombre del Cabildo diezmos de heredades que se vendían, de capas o de cualquier otra cosa.

En virtud a la Constitución dada el 23 de marzo de 1423, contenida en las constituciones dadas por Tavera en 1539, se mandaba al refitolero, receptor o al que le incumbiese el cobro de la deuda amonestar al deudor delante de dos o tres beneficiados para que le pagara lo que le debiese, y pasados 15 días sin contestación, el repartidor dejaría de escribirle las horas, y el deudor dejaría de ganar pan, sal, distribuciones, aniversarios y cualquier otro emolumento de la iglesia hasta que no pagara lo que debiese ${ }^{99}$.

\footnotetext{
97 ACT, AC, vol.16, f.88r.

98 ACT, OF-1458, f.1v.

99 ACT, FS I, 2, f.41v-43r.
} 
Así pues, también se mandaba que el recudimiento no se otorgara a los canónigos que, teniendo el vestuario en suerte, debiesen alguna cantidad por demasía entre el importe de su vestuario y lo ganado por su residencia. El 7 de diciembre de 1565 el Cabildo mandaba al secretario que se notificara un mandamiento general para que no se diera recudimiento al señor don Fernando Bazán a petición del Jurado Rodrigo de la Fuente ${ }^{100}$. Días después, también se le notificaba al Cabildo un mandamiento del vicario general en el que se mandaba que no se diera la suerte y recudimiento de los vestuarios al canónigo Valera ${ }^{101}$.

La deuda anterior a otorgar el recudimiento debía depositarse en el arca de vestuarios. En caso de que el canónigo deudor no respondiera al requerimiento del pago de la deuda, se procedía al embargo. El 4 de junio de 1572 el Cabildo manda el embargo del vestuario del canónigo Fernando Bazán, "atento que le debe dineros" ${ }^{102}$.

El recudimiento, firmado y sellado por el Cabildo y con el refrendo del secretario, autorizaba particularmente a cada canónigo para cobrar su vestuario ${ }^{103}$ :

...el señor y hermano nuestro $\mathrm{N}$ como canónigo a de auer cobrar y recibir por nos y en nuestro nombre y para si mismo para el pago de lo que perteneció por razon de su vistuario de este dicho año todo el pan y mrs de $\mathrm{N}$ y $\mathrm{N}$ que son en el arciprestazgo de $\mathrm{N}^{104}$.

De la misma forma, reconocía la autoridad del canónigo en cuestión para el cobro ante todos los arrendadores, dezmeros, terceros, deganos, fieles y cogedores y cualquier persona que hubiese cobrado y recibido en arrendamiento, en fieldad o en tercería o de cualquier otra forma, los frutos y rentas decimales. A éstos se les instaba a acudir con el pan y los maravedís ante el canónigo en cuestión o a "quien su poder ouiere".

En el cobro solía intervenir un receptor de vestuarios elegido por el Cabildo. Éste o el canónigo beneficiario o el que los tomase en su

\footnotetext{
100 ACT, AC, vol.12, f.222r.

101 Ibid., f.223r.

102 ACT, AC, vol.15, f.309v.

103 El modelo de carta de recudimiento para la cobranza de los vestuarios se encuentra en ACT, OF-909, f.208r.

104 ACT, OF-909, f.208r.
} 
nombre, una vez recibido el importe, otorgaría la carta de pago, el documento en el que el acreedor declaraba haber recibido el importe completo o parte de la deuda. A su vez, el que los pagase al canónigo debía recibir una carta de pago. Ésta y un traslado del documento de recudimiento, signado del escribano o notario, sería la prueba necesaria para demostrar el pago, recibiéndosele a la presentación de ambos documentos en cuenta. En caso contrario, que el que los pagase no pudiese demostrar el pago, el Cabildo daba poder al canónigo para pedir y demandar todo el pan y los maravedís que le correspondiesen ante cualquier juez y justicia eclesiástica y seglar y hacer sobre ello cualquier demanda, pedimento, requerimiento y diligencia que conviniese y que fuera menester.

\section{- La gestión de los vestuarios por un receptor}

En principio, las rentas de vestuarios se cobraban en el refitor. Esto en virtud a las constituciones de 1357 dadas por don Blas Fernández de Toledo en las que se mandaba al refitor cobrar las rentas de la mesa capitular, recibir el dinero de los vestuarios y distribuirlo entre los canónigos $^{105}$. Con posterioridad se hizo habitual recurrir a un receptor de vestuarios. De él daba noticia el canónigo doctor Blas Ortiz en 1549, cuando tratando "de los oficiales, assí del Cavildo, como de la Fábrica de la Santa Yglesia" decía: "ay también un receptor de las rentas de los vestuarios, esto es la décima parte de todos los diezmos de trigo y vino, que pertenece sólo a los canónigos, y aviendo residido se distribuye entre ellos"106.

Entre los receptores predominaban los canónigos y racioneros, muchos de ellos miembros de la burguesía mercantil de la ciudad ${ }^{107}$, situación por otro lado nada extraña en estas corporaciones. Estos hombres en muchos casos con sobradas aptitudes para los negocios, habían convivido en un ambiente familiar propicio ${ }^{108}$ y contribuirían poco a poco a cambiar la concepción que se tenía de este colectivo ${ }^{109}$.

\footnotetext{
105 M.J. Lop Otín (2003) op. cit., pp. 290-291.

106 B. Ortiz (1549) Sumi Templi Toletani perquam graphica Descriptio, La Catedral de Toledo. Toledo: Antonio Pareja [1999], p. 283.

107 J.C. Gómez-Menor (1970) Cristianos nuevos y mercaderes de Toledo. Notas y documentos para el estudio de la sociedad castellana del Siglo XVI. Toledo: Ed. Zocodover, p. XV.

108 J.J. Lanero Fernández y E. Ortega Montes (2005) "Naturaleza y significado de los libros de cuentas de John Isham, mercader de Isabel I, reina de Inglaterra", Pecvnia, 1, p. 150 y ss. Editorial, pp. 114-115.

109 J. Le Goff (2004) Mercaderes y banqueros de la Edad Media. Madrid: Alianza
} 
Aunque la presencia del receptor era habitual no se descartaba que fuera el propio canónigo el que se ocupara directamente de su vestuario, llegándose incluso a plantear con carácter general la exclusión del primero, como trataremos más adelante. No era tampoco menos raro que el canónigo entrara en el remate de su vestuario, haciéndose cargo de la gestión del mismo, pues las condiciones de arrendamientos de $1530^{110}$ preveían que cualquiera de los canónigos que sacasen renta en el estrado rematado en él, pudiera tomar vestuario. No así podían dos canónigos tomar vestuario en una renta, ni menos tomar vestuario en renta que se rematare en algún arrendador si no fuera rematada en el mismo canónigo. Así, el canónigo que sacase renta no pagaba al receptor, excepto su salario antiguo de $10.000 \mathrm{mrs}$. Además, si algún arrendador con poder de algún canónigo que estuviera ausente, porque los presentes no puedan cambiar renta por precio, sacaba renta, el canónigo ausente podía tomar en ella su vestuario, obligado en toda la renta, no estando obligado a pagar el salario al receptor salvo lo del salario antiguo, y puesto en poder del arrendador antes de las rentas de postrero remate y ante el secretario del Cabildo.

Los receptores de vestuarios eran elegidos y nombrados por el Cabildo en capítulo, tras las recomendaciones sobre la idoneidad del candidato. Antes, por el mes de octubre se solía comisionar a dos canónigos para que entendieran en procurar el receptor de vestuarios que conviniese. También se ponían cédulas para nombrar receptor de vestuario, ordenándose a los diputados que entendieran de ello. Esto se hacía en uno de los tres cabildos que mandaba celebrar la Constitución desde el día de Todos los Santos a Navidad ${ }^{111}$ y donde se declaraba también quién ganaba vestuarios y quién los perdía y el resto de las cosas que se mandaban al respecto. El receptor elegido debía gestionar los vestuarios, cobrando su salario de cada uno de los canónigos que lo habían ganado. En 1532 el salario era de $2.250 \mathrm{mrs}$ de cada uno ${ }^{112}$, incrementándose al año siguiente hasta 2.900 $\mathrm{mrs}^{113}$.

A lo largo del siglo XVI diferentes personajes desempeñaron sus funciones como receptor de vestuarios. Algunos de éstos son los

\footnotetext{
110 ACT, OF-1454, f.4r.

111 Éstos, aunque la constitución mandaba hacerlos en tres días, se acostumbraron a hacer en uno.

112 ACT, OF-1454, f.27r.

113 Ibid., f.36v.
} 
siguientes: Antón López $(1513)^{114}$, el protonotario y canónigo Palomeque $(1517)^{115}$, Lucas de las Peñas, los canónigos Rodrigo Ortiz y Antonio de León $(1528)^{116}$, el capiscol Bernardino Zapata y el canónigo Francisco de Silva $(1530)^{117}$, el racionero Gutierre Hurtado $(1532)^{118}$, el refitolero Pablo Provencio, Fernando de Bazán, el canónigo Antonio de León (1548) ${ }^{119}$, etc.

Tras la elección, el secretario hacía público el nombramiento, asumiendo el receptor ante el notario del Cabildo las obligaciones de sus antecesores y comprometiéndose a recibir los vestuarios por su cuenta y riesgo. Junto a las exigencias personales de los electos, el nombramiento era reforzado con la petición de fianzas llanas y abonadas, por su implicación en el manejo de rentas, al igual que para algunos oficiales públicos ${ }^{120}$.

Las fianzas debían presentarse ante el Cabildo y ser de conformidad de éste. El presentar fiadores tenía un objeto evidente, respaldar económicamente la actuación de los elegidos y, sobre todo, cubrir las posibles pérdidas ocasionadas por conductas negligentes, obligándose por su persona y bienes muebles y raíces, espirituales y temporales, habidos y por haber. Las fianzas no debían coincidir con las presentadas por los arrendadores de las rentas de ese año ni del pasado. Desde el momento en que se presentaban las fianzas, los fiadores se suscribían en las mismas condiciones que lo hacía el receptor en cuestión, poniendo en compromiso "personas, bienes muebles e raíces a vidas", sometiéndose en todo lo necesario a la Justicia de la ciudad de Toledo y a los conservadores y subconservadores del Cabildo. De esta forma, juraban cumplir todo lo contenido en el contrato "para mayor firmeza", sin pleito, ni contienda de juicio.

El receptor de vestuarios, desde el momento de su nombramiento, contaba con todo el poder necesario para "cobrar, reciuir, auer e demandar" los vestuarios, pudiendo cobrarlo directamente o mandarlo cobrar de los arrendadores. Fuera cual fuera el proceder, era el responsable

\footnotetext{
114 ACT, AC, vol.4, f.61r.

115 Ibid., f.140v.

116 ACT, AC, vol.5, f.19v.

117 ACT, OF-1454, f.4r.

118 Ibid., f.27r.

119 ACT, AC, vol.8, f.88v.

120 En el Ayuntamiento de Toledo el mayordomo que daba cuenta de la hacienda y rentas de la ciudad estaba obligado, tras su nombramiento, a dar fianzas de personas legas, llanas y abonadas. Ordenanzas para el buen régimen y gobierno de la ciudad de Toledo. Toledo, 1858, p. 148.
} 
en última instancia y debía responder ante el Cabildo de cualquier contratiempo. Una vez contraída la responsabilidad y antes del cobro, los receptores debían presenciar la toma de fianzas a los arrendadores como uno de los cuatro diputados designados por el Cabildo para tomar las fianzas, teniendo capacidad para pronunciarse sobre la aceptación de las mismas, aunque su decisión no invalidaba las del resto.

Los plazos en que los arrendadores de vestuarios debían satisfacer la paga quedaban estipulados en el contrato de arrendamiento. Cuando el arrendador no acudía al cobrador de rentas nombrado por el Cabildo para satisfacer su deuda, caía en impago. Era entonces cuando el último, con el poder otorgado por el Cabildo, tenía potestad para pedir y requerir ante cualquier juez y justicia eclesiástica o seglar el pago de las rentas. Asimismo, este poder otorgado al receptor le facultaba para hacer todas las demandas, pedimentos, requerimientos y diligencias que fueran menester para conseguir el pago de la deuda.

El receptor cada año debía dar cuenta al Cabildo de su gestión. En sesión capitular el 11 de octubre de 1549 se mandaba que se pusiera por condición de aquí en adelante que cuando se recibiese un receptor de vestuarios que a los cuatro meses después de la postrera paga trajera el libro con las cuentas al Cabildo ${ }^{121}$.

- Una propuesta para la gestión de los vestuarios por parte de los canónigos

Lo habitual, como se ha visto, era que el cobro de las rentas de vestuarios se hiciera a través de un receptor de vestuarios. A pesar de la costumbre, el sábado 1 de diciembre de 1548 el Cabildo se reunía convocado por cédula ante diem para "dar el mejor medio que parese en la cobrança de las rentas de vistuarios en leyes e ciertos capitulos" $^{\prime 122}$. La propuesta pretendía que los canónigos gestionaran su propio vestuario, dando las pautas necesarias para proceder en tal caso. La propuesta finalmente fue rechazada con la mayoría de los votos de los canónigos, optando por continuar con el procedimiento habitual y los servicios del receptor. Aún así, por lo interesante del tema trataremos de ello a continuación.

\footnotetext{
121 ACT, AC, vol.8, f.140v.

122 Ibid., f.87r.
} 
La idea era que después de rematados los vestuarios y con los aliceres del precio se hicieran trece suertes iguales en las que cupiesen tres vestuarios en cada una. Las suertes se harían, como era costumbre, tomando los veinticinco arciprestazgos y teniendo en cuenta lo que valía la renta de cada uno, dando o quitando hasta que estuvieran iguales. De manera que si hubiese alguna diferencia en alguno de los partidos fuera para la paga que de dichas rentas cabía al subsidio y los otros gastos aparejados a los vestuarios.

Una vez que las suertes estuviesen igualadas, se nombrarían trece canónigos para que cada uno se encargase de cobrar un partido. Para adjudicar el cobro a estos canónigos se tomarían sus nombres en unos papeles, que se echarían en una jarra y las suertes o partidos en otra. De la primera jarra se sacarían los nombres, de manera que según iban saliendo se les adjudicaría la cobranza, tomando de la otra jarra el papel correspondiente a la suerte. Hecha tal adjudicación, los canónigos elegidos debían presentar fianzas para asegurar la renta o rentas que les cupiesen por suerte de su partido.

Después de adjudicar el cobro a los trece canónigos, se tomarían los nombres de los canónigos restantes que ganaron vestuario ese año, escribiéndose en un papel y echándose a uno de los cántaros. Luego se cogerían los nombres de las trece suertes y se echarían por duplicado en otro cántaro. Por ejemplo, el arciprestazgo de Ocaña puesto dos veces en dos papeles diferentes, el arciprestazgo de Montalbán otras dos veces, y así sucesivamente. De esta manera, para realizar el sorteo se tomaría un papel de un cántaro y otro de otro y se iría haciendo la adjudicación. Cada suerte quedaría repartida para tres canónigos y de entre estos tres, uno de ellos se dedicaría al cobro de su partido.

A los trece canónigos nombrados para el cobro de los partidos se le tomaría cargo de la fianza a contento suyo y de los canónigos que compartieran con él el partido a cobrar. Estas fianzas se presentarían también conforme a las condiciones con que se remataban las rentas de vestuarios ese año, reconocidas en el contrato. En dicho contrato los arrendadores y los fiadores de estos últimos reconocerían igualmente que pagarían a los tres canónigos que salieran nombrados para tal partido, a cada uno lo que hubiese de haber de la renta de su vestuario. El pago se produciría la mitad el día de Nuestra Señora de agosto de 1549 y la otra mitad el día de San Miguel en septiembre de ese año, conforme a las mencionadas condiciones. 
Para la concesión de fianzas, como se acostumbraba, se procedería al nombramiento de diputados, que siendo bastantes, otorgarían la concesión, si así lo estimasen por ser las rentas llanas y abonadas. Si la renta del partido a cobrar quebrara antes de la toma de fianzas, la quiebra correría por cuenta del Cabildo, no así si estuviese afianzada. En este último caso correría a cargo de los que afianzaran y no del Cabildo.

Los tres canónigos debían dar poder y recudimiento de forma conjunta para la cobranza de lo que correspondía al partido, tomando de cada partido o en cada suerte su vestuario de mano de los arrendadores. El importe debía repartirse entre los tres canónigos que lo debían recibir. Sin embargo, podría ocurrir que el que saliese nombrado por principal para la administración y cobranza cobrase su prebenda enteramente en la primera paga y quedasen los otros agraviados esperando la renta. Por eso en el contrato se debía recoger expresamente que la carta de pago que se diese al arrendador, justificando el recibimiento, debía ir firmada por los tres canónigos que debían cobrar la renta de manera conjunta. En caso de que el cobro correspondiese a uno de los canónigos individualmente, la firma sería la de este último por el dinero que correspondiese a su parte.

Desde el Cabildo se instaba a elaborar un libro, diferente al que se solía dar al receptor de vestuarios, elaborado por el secretario, y donde figurase el remate de las rentas, el precio y las personas en las que se rematase. A continuación se pondrían las suertes de los partidos, cada uno por sí mismo, y los tres canónigos a los que cupiese la suerte y el partido, de tal manera que para que en pago de sus vestuarios del fruto de ese año se diera la correspondiente paga por parte de los arrendadores. Este libro debía estar en el Cabildo para que se asentase lo que fuese menester a contento de los que hubieron de cobrar en los partidos.

Además del libro mencionado más arriba, debían llevarse los otros libros que se acostumbraban, tal como se reconoce: "Demas del dicho libro ha de aver los otros ordinarios de remate de vestuarios, de contratos e repartimiento particular de las rentas. ${ }^{123}$.

Para el que fuese a ejecutar el cobro, debían recoger las condiciones que se pagase medio ducado $(187,5 \mathrm{mrs})$, pues hasta el momento se pagaban cuatro reales (136 mrs), reconociéndose que venía a ser poco "y el que hubiere de yr a cobrar presume que ha ser persona que 
lo sepa hazer y que meresca el dicho salario"124. Por su parte, lo que gastase en la cobranza y otras cosas tocantes a esto debía ser a costa de los tres canónigos.

Si en la cobranza del remate a los arrendadores se declarase quiebra o descuento por error en las copias de las rentas, se prescribía que esto debía quitarse de las rentas de Baza de ese año. Estas rentas decimales, exclusivas de los canónigos y compartidas con el cabildo de Guadix, era frecuente que se usasen para la cobertura de faltas, impagos o descubiertos en los vestuarios. Aunque se repartían separadamente, en ocasiones se unían y repartían con ellos, según acuerdo en capítulo.

Como hemos adelantado más arriba, la propuesta que aquí se describe no obtuvo la aprobación. Pues, sometida a votación en sesión capitular, fue rechazada por la mayor parte de los canónigos, aunque el voto estuvo reñido. Unos canónigos, a la cabeza de los cuales se encontraba el capiscol Bernardino Zapata, pretendían que el cobro de los vestuarios corriera por cuenta de los canónigos personalmente y se cumpliese lo establecido en la propuesta. Otros, sin embargo, eran de la opinión del Doctor Ortiz y consideraban que se debía seguir con la costumbre de nombrar un receptor de vestuarios. Como decimos, la votación terminaría siendo favorable a que no se hiciera novedad, nombrándose en esa misma sesión al canónigo Antonio de León como receptor de vestuarios.

\section{- El pago de su vestuario a los canónigos}

En principio, era el receptor el que acostumbraba, tras recibir el importe del arrendamiento, a pagar a los canónigos según la distribución del secretario, anotada en un libro particular que se le entregaba cada año. Antes debía hacer frente a los gastos previstos y a los descuentos estipulados, procediendo posteriormente a dar cuenta de todo ${ }^{125}$.

Las pagas debían hacerse en el tiempo previsto, pues 10 días después de pasado el plazo en el que el receptor acostumbraba a pagar, si el canónigo quedase insatisfecho con la actuación, éste podía recurrir a la Justicia seglar o eclesiástica, como mejor conviniese. Para

\footnotetext{
124 Idem.

125 ACT, OF-909, f.206r.
} 
esta reclamación el canónigo no necesitaba el beneplácito del Cabildo, sino solamente la fe del secretario ${ }^{126}$.

Si el receptor persistía en su deuda con los canónigos que tuviesen derecho a percibir sus rentas, éste perdería todo el salario que debía recibir de cada uno de los canónigos con los que mantuviese la deuda. También al canónigo afectado se le reconocería el derecho a tomar las personas y bienes del receptor y de sus fiadores, pasados los diez días pertinentes ${ }^{127}$.

No era infrecuente que el efectivo del vestuario no llegara, al menos en su totalidad, a manos de los canónigos que lo habían ganado. Más bien era habitual que fuera a cuenta de deudas contraídas con el Cabildo por algún préstamo o por deudas con terceros. Éstas eran pagadas por el receptor de vestuarios con el libramiento previo del titular de la cuenta a costa de su vestuario. En este último caso, el canónigo escribía al receptor informándole de su situación y confiriéndole el poder necesario para resarcir la deuda con el importe de su vestuario, indicándole la cantidad, la forma y los plazos de pago. A esta notificación le acompañaba otra liberándole del compromiso contraído con el canónigo por el pago, para que fuera utilizado por el receptor como prueba en su descargo. En 1519 el canónigo Peralta escribía al receptor de vestuarios Lucas de las Peñas en los siguientes términos:

Reverendo Señor Lucas de las Peñas canonigo desta Santa Iglesia de Toledo y rrecebtor de los vestuarios de los canónigos della de los maravedis que uvo de aver de my vestuario deste año de myll e quinientos y dieznueve mando a vuestra merced dar al Señor canonigo Juan Lopez de Leon quarenta ducados que me presto los quales vuestra merced le a de dar a los plazos que yo tengo de ser pagado del dicho vestuario con la primera paga y reciba vuestra merced su carta de pago en las espaldas desta cedula con la qual yo me dy por contento y pagado de los dichos quarenta ducados hecho a quince de octubre de myll y quinientos y diecinueve años son quarenta ducados. Licenciado Peralta ${ }^{128}$

\footnotetext{
126 ACT, OF-1454, f. $4 \mathrm{v}$.

127 Ibid., f.4v.

128 ACT, OF-1450.
} 
A la vuelta de dicha notificación hacía el receptor reconocimiento del compromiso. La confirmación del receptor Lucas de las Peñas sería la siguiente:

Yo Lucas de las Peñas canonigo en la Santa Iglesia de Toledo Recebtor de los vistuarios digo que se pagaran estos quarenta ducados al Señor Juan Lopez canonigo en los plazos que soy obligado a pagar segun se contiene en esta çedula fecha XV dias del mes de octubre de IUDXIX años. Lucas de las Penas. Canonicus Toletani.

Era posible también que el vestuario no llegara a manos del canónigo y fuera embargado por decisión del Cabildo. Este embargo le podía sobrevenir al canónigo por alcances en contra derivados de una mala gestión a la cabeza de alguna receptoría del Cabildo, de la Obra y Fábrica o de cualquier fundación o memoria. Así pues, al tiempo de las pagas del vestuario y periódicamente se hacían ingresos en la Tesorería a favor de la entidad acreedora. Fue el caso del embargo del vestuario del canónigo Diego López de Ayala por deudas contraídas con el Cabildo y con la hacienda de Diego López de León. Para resarcir parte de la deuda, el 12 de enero de 1562 el prior Cebrián hacía un ingreso en el arca de depósito, custodiada en el sagrario, de $147.420 \mathrm{mrs}$ del vestuario del fruto de 1560. El prior lo cobró y benefició por comisión del Cabildo hasta que se averiguase y pagase lo que el mencionado Diego López de Ayala debía. La operación se ejecutó en presencia de los dos canónigos Miguel Díaz y Leonardo Ortiz y del tesorero García Manrique, depositarios de las tres llaves del arca de depósitos, y del secretario que tomaría nota al pie del arca en la forma prescrita para estos $\operatorname{casos}^{129}$.

La facilidad para el embargo pudo hacer más adecuado el que los canónigos ocuparan puestos de responsabilidad económica, pues así era fácil resarcir la deuda generada por una mala gestión. La misma razón por la que resultaba más conveniente el arrendamiento de las propiedades capitulares y la concesión de censos a los beneficiados. La cesión a beneficiados permitía al Cabildo garantizar en caso de impago la renta con la retención de su estipendio.

El pago del vestuario también podía verse afectado por yerro o quiebra en alguna de las suertes de dinero o de pan, lo que perjudicaría al canónigo al que cupiera. Para solventar la falta de remate

129 ACT, OF-1328, f.37r. 
en las rentas de 1549, el 16 de diciembre de ese año el Cabildo mandaba que si ocurriese, se pagara al canónigo con el dinero de la renta de Baza de ese mismo año. Para que el canónigo viera compensado su derecho de cobro con estas rentas, previamente y por mandato del Cabildo el canónigo de la suerte quebrada debía informar a éste sobre las causas de la quiebra durante el mes de abril de $1550^{130}$. Por lo demás, mandaba al mismo que si hubiese alguna dita o efecto en garantía de pago que no hubiese sido cierto, siendo ésta la causa de la quiebra, hiciese las diligencias necesarias contra el arrendador y sus fiadores. Si no fuera obligado, el canónigo podía cobrar del mayordomo, notificando antes las diligencias al Cabildo. Éste, cuando recibía la notificación, iría contra el mayordomo a cuyo cargo estaba el afianzar las rentas y hacer pagar la dita a quien correspondiese ${ }^{131}$.

El yerro de las copias se podía cubrir con lo extraído de los gastos de vestuarios, siendo ésta otra solución alternativa. Así, el 24 de octubre de 1592 el Cabildo manda librar al licenciado Cordobés en gastos de vestuarios 405 reales. Esto era lo que suponía un error detectado en la copia de su suerte que le cupo en la partida de pan de los lugares de Los Villares y Corral de Torcón, pues dicha copia, que daría Joan Gómez de Chaves para los vestuarios, se dio por pan, trigo y cebada y al remate fue sólo de cebada, montando la diferencia 101 fanegas y 3 celemines ${ }^{132}$.

A la hora de ejecutar el pago de la suerte, podía ocurrir que ésta correspondiese a un canónigo residente fallecido, entonces el Cabildo antes del pago a sus herederos retenía el vestuario al objeto de saldar posibles deudas contraídas por el finado. El 23 de septiembre de 1577 el deán informaba que se había cobrado y mantenía en su poder el vestuario de Leonardo Ortiz, 584.002 mrs., que había empleado en pagar $25.000 \mathrm{mrs}$ al vecino de Alcalá Alonso Ribera por cobrarlo y beneficiarlo, $44.000 \mathrm{mrs}$ a Tomás de Borja y $6.800 \mathrm{mrs}$ a Miguel Díaz de una deuda. El resto, $508.202 \mathrm{mrs}$, se habían entregado al racionero Canipo para que se mantuvieran en depósito y pagase $197.000 \mathrm{mrs}$ que el finado debía al Cabildo y refitor y otras tantas deudas a capitulares que lo tenían reconocido por cédula, tomando carta de pago a las espaldas de cada cédula "y que digan que los volveran sino estuvieren bien pagados", dando el Cabildo

\footnotetext{
130 ACT, AC, vol.8, f.152v.

131 Ibid., f.152v.

132 ACT, AC, vol.20, f.273v.
} 
por libre al deán de 584.002 mrs. "por hauerlas entregado según dicho es"133.

Cuando el canónigo declarado ausente hacía las reclamaciones pertinentes y lograba que se le reconociese su residencia, el pago a veces debía ejecutarse con efectos retroactivos, lo que obligaba a rectificar un reparto ya hecho. En este caso se actuaba detrayéndolo de las ganancias de los canónigos que lo habían cobrado sin deberlo hacer. El 1 de diciembre de 1573 se mandaba que lo que se veía obligado a pagar al canónigo Diego de Guzmán de Silva por razón de tres vestuarios que perdió se quitase de los tercios ${ }^{134}$ que se pagaban del refitor de finales de diciembre de cada año a cada uno de los canónigos que lo habían ganado conforme a la parte que cada uno llevó de los mencionados tres vestuarios $^{135}$.

\section{OTRAS GANANCIAS QUE SE REPARTEN A LOS CANÓNIGOS}

Eran privativas de los canónigos en este tiempo, junto a los vestuarios, las rentas del préstamo de Hita, los aliceres, las ausencias y los cabildos, extraídos de las copias de los propios vestuarios para ser repartidos por separado cuando se hiciera la distribución de éstos, además de las rentas del préstamo de Baza.

\section{- El préstamo y los aliceres de Hita}

El préstamo o prestimonio lo constituía la tercia pontifical compartida con el clero catedralicio ${ }^{136}$. Lo que restaba una vez sacado el medio diezmo o aliceres de Hita se conocía como rentas del préstamo de Hita. Estas rentas eran de pan y vino de los arciprestazgos de Hita y Brihuega, de las que llevaban los canónigos de Toledo un diezmo entero de las rentas pontificales; y en las rentas de los excusados, un diezmo y

133 ACT, AC, vol.16, f.131v.

134 Los tercios o caridades remuneraban la residencia del trimestre de los canónigos y racioneros. Por tanto, la ganancia se vinculaba a la asistencia de éstos a determinados oficios cada día a lo largo de cada trimestre, marcados en el calendario del repartidor como de caridad, no de distribución.

135 ACT, AC, vol.15, f.393.

136 M. Santamaría Lancho (1982) "La organización de la gestión económica del cabildo catedralicio de Segovia. Siglos XIII-XIV", Estudios en memoria del Profesor D. Salvador de Moxó, II, p. 513. 
un "sesmo" o sexto del diezmo. A más de esto, de todo el pan y vino de los lugares de orden o encomienda se sacaba un diezmo y del resto otro diezmo, de ello la tercera parte era para los canónigos ${ }^{137}$.

Los aliceres de Hita consistían en la mitad del diezmo de las rentas de los canónigos. Éstos se juntaban al importe de los vestuarios y se repartían con ellos entre los que ganaban vestuario ese año.

Las rentas del Préstamo se repartían anualmente entre todos los canónigos prebendados de la Iglesia de Toledo que no fueran dignidades en ella ${ }^{138}$, según se recoge en la constitución dada por el arzobispo Alonso Carrillo, el 27 de julio de $1462^{139}$. Por ello, tenían derecho a estas rentas desde el día que tomasen posesión de su canonjía, aunque no residiesen, ni hubiesen residido nunca, "ni nunca hayan venido o vengan a la Iglesia"140. El período de devengo de estas rentas sería de un año a contar desde San Miguel en septiembre. Para el reparto se tomaban "...todos los dias que fuere canonigo donde quiera que resida..."141 y el secretario del Cabildo, encargado de organizar el reparto, lo hacía tomando un listado con el número de canónigos con derecho a estas rentas. Seguidamente, considerando los 365 días del año ó 366 días en caso de ser el año bisiesto, se averiguaba la cantidad por día que correspondía a cada canónigo.

Para la distribución de los importes entre los canónigos era necesario contemplar el número de canónigos que entraban nuevos el mencionado año y los que murieron. La razón de esto era conocer el número de días que habían sido canónigos ese año, con el objeto de hacer un reparto justo de las rentas: "...y repartir la cantidad que se ouiere de repartir por aquellos dias y sabido quanto cabe a cada dia darle a cada canonigo conforme a los dias que tuuiere ${ }^{142}$. En 1579, considerando la canonjía del Santo Oficio de la Inquisición, los enteros y los quebrados, es decir, los que lo ganaron por entero y los que no, fueron 35 canónigos que suponían 11.726 días. Importó cada día $41 \mathrm{mrs}$. y 7 dº, recibiendo el que lo ganó entero, porque fue canónigo durante los 365 días del año, $15.230 \mathrm{mrs}^{143}$.

\footnotetext{
137 ACT, OF-909, f.229r.

138 Ibid., f.229v.

139 ACT, I.9.1.10.

140 ACT, OF-909, f.229v.

141 Ibid., f.256r

142 ACT, OF-909, f.230r.

143 ACT, OF-528, f.3r.
} 
El pago de lo que importaba el préstamo se solía hacer en los tercios acostumbrados (abril, agosto y diciembre) ${ }^{144}$, aunque se llegaría hacer en dos plazos.

\section{- Los cabildos}

La asistencia a los tres cabildos que mandaba celebrar la Constitución desde el día de Todos los Santos a Navidad para tratar los asuntos de los vestuarios se incentivaba con ciertos importes, que se extraían de las rentas antes del reparto, y después de quitar lo que correspondía a los ausentes, según Estatuto dado el 2 de noviembre de 1435 y contenido en las Constituciones dadas por Tavera en 1539 ${ }^{145}$. En virtud a esto, cada año debían extraerse del remanente, después de sustraer lo que correspondía a las ausencias de privilegiados, $18.000 \mathrm{mrs}$ para repartir a partes iguales en los tres cabildos mencionados, es decir, 6.000 mrs para cada uno. Con el tiempo se aumentaría la dotación reservada para los cabildos a 34.000 mrs.

Los cabildos, convocados por cédula del deán o de su lugarteniente donde se contenía el negocio a tratar, eran: el primero para hacer y declarar las condiciones del arrendamiento de los vestuarios; el segundo, para nombrar el receptor; y el tercero, para declarar las ausencias de los canónigos que no ganaron vestuario. No obstante, aunque esto era lo que mandaba la constitución, se acostumbraron a celebrar en un único día.

\section{- Las ausencias}

Procedían de lo que dejaban de ganar los que no residían sin autorización. Para ganar las ausencias, los canónigos debían presentarse en principio a tres puntos de asistencia señalados: las primeras vísperas, maitines y misa mayor de las fiestas de Todos los Santos, Pascua de Resurrección y Santa María de agosto de cada año. Aunque este requerimiento cambiaría el 29 de octubre de 1507 y después el 12 de julio de 1508, cuando se excusó de asistir a maitines de las tres fiestas, mandando el Cabildo que el primero de maitines se ganase a segundas vísperas de cada fiesta. Por lo tanto, las ausencias pasarían a ganarse a primeras

\footnotetext{
144 ACT, OF-527, f.2r.

145 ACT, FS I, 2, f.46r.
} 
vísperas, misa mayor y segundas vísperas y en los maitines de las tres fiestas se daba a la ración 4 reales y a la media ración 2 reales ${ }^{146}$.

Atendiendo a los requerimientos de asistencia, para repartir el dinero de las ausencias se hacían tercios, que correspondían con cada una de las tres fiestas. De cada uno de estos tercios se harían, a su vez, otras tres partes para el prorrateo de los tres puntos y cada una de estas partes se repartía a partes iguales entre los canónigos y dignidades que residían y ganaban su vestuario según lo prescrito ${ }^{147}$.

Podía ocurrir que el canónigo ausente no fuese dado por privilegiado para no residir, en tal caso los 60 florines que se hubiesen apartado de su vestuario se repartirían entre los canónigos presentes o excusados por enfermos, atendiendo a los tercios hechos para cada una de las consabidas tres fiestas, momento en el que se produciría el reparto. No entraban en dicho reparto los canónigos que hiciesen su primera residencia anual. Así, las ausencias de cinco canónigos, que importaban $79.500 \mathrm{mrs}$ se repartían entre los canónigos y dignidades asistentes, considerando $26.500 \mathrm{mrs}$ en cada uno de los tres puntos (Todos los Santos $^{148}$, Pascua de Resurrección ${ }^{149}$ y Santa María de Agosto ${ }^{150}$ ).

La distribución se hacía atendiendo a la lista de nombres de canónigos presentes o enfermos que tomaba el repartidor en cada una de estas fiestas. Estando en el mismo punto de asistencia, se debía acudir con el libro a los mayordomos, para que allí vieran cuántos canónigos ganaban en la fiesta y cuánto debía cobrar cada uno, firmándolo con sus nombres ${ }^{151}$.

Por último, en la sesión capitular a la que hemos hecho referencia anteriormente, de 16 de diciembre de 1549, se mandaba quitar a los canónigos el importe que no ganaban enteramente de aliceres, cabildos y ausencias, obligándoles a devolverlo al arca antes de darles recudimiento ${ }^{152}$.

\footnotetext{
146 BCT, Arcayos (copia), vol.1, f.16r.

147 ACT, OF-909, f.204r.

148 ACT, OF-1452, f.10v.

149 Ibid., f.11r.

150 Idem, f.12r.

151 Idem, f.205r.

152 ACT, AC, vol.8, f.152v.
} 


\section{- El préstamo de Baza}

Desde la Concordia de 1544, por la que se resolvió el conflicto que Toledo mantenía con el obispo de Guadix, Baza y los lugares de la Hoya quedaron para el obispado de Guadix y la jurisdicción en segunda instancia correspondía a la metrópoli de Toledo ${ }^{153}$. En lo económico, el arzobispo y el cabildo de Toledo percibirían de Baza y sus tierras un tercio de las rentas del prelado y el cabildo de Guadix, sin gasto y costa de sacarlo y averiguarlo ${ }^{154}$. Mientras, la jurisdicción sobre la vicaria de Huéscar y Bolteruela y sus anexos sería de la dignidad arzobispal toledana, que cedería la tercera parte de lo que allí incumbía al prelado y cabildo para el obispo y cabildo de Guadix ${ }^{155}$.

Lo que Toledo obtenía de estas rentas era lo que se conocía como préstamo de Baza y correspondía al reparto de los diezmos de Huéscar y La Puebla. En 1550 de las rentas de Huéscar el duque de Alba recibía dos novenos de los diezmos, el arzobispo de Toledo y el obispo de Guadix compartirían un cuarto, el cabildo de Toledo y el de Guadix tenían un onceavo y los beneficiados y Fábricas de las iglesias de Huéscar y La Puebla se repartían el resto ${ }^{156}$. De otra forma, el reparto de los diezmos en estos lugares era aproximadamente de un 22,22\% para el duque de Huéscar, el $25 \%$ para los obispos de Toledo y Guadix (16,6\% para el de Toledo y $8,4 \%$ para el de Guadix), el $9,1 \%$ para los cabildos de Toledo y Guadix (6,06\% para el de Toledo y 3,04\% para el de Guadix) y el resto, 43,68\%, para los beneficiados y Fábricas de las iglesias de Huéscar y La Puebla.

En Toledo lo que importaba las rentas del préstamo de Baza debía distribuirse a partes iguales entre los canónigos que hubiesen ganado vestuario ese año, "... aunque sean dignidades que ganan esto aquel año de que son los diezmos por y quales partes y el que no gano vestuario aquel año no se le da parte de ello"157.

153 P. Suárez (1948) Historia del obispado de Guadix y Baza. Madrid: Artes Gráficas Arges, pp. 397-404. ACT, I.1.B.5.3., f.7v.

154 ACT, I.1.B.5.3., f.7r.

155 P. Suárez (1948) op. cit., pp. 397-404. ACT, I.1.B.5.3., f.8r.

156 Sobre el reparto detallado de esta parte véase H. Rodríguez de Gracia (2000) "Las tierras arzobispales en el Adelantamiento de Cazorla", Boletín del Instituto de Estudios Giennenses, 176, p. 1.009.

157 ACT, OF-13, f.1r. 
Antes del reparto y como se acostumbraba a hacer para otras rentas, debían restarse todos los pagos por gastos aparejados a estas rentas más las retenciones del subsidio al rey, lo que hacía que la parte que quedaba para repartir entre los canónigos fuera menos de lo deseado, llegando a ser a veces tan pequeña que posiblemente terminaba depositada en el arca de vestuarios para cubrir la faltas en las copias de estas rentas o para terminar de pagar el subsidio ${ }^{158}$.

\section{CONCLUSIONES}

El vestuario constituía la gruesa de una canonjía en Toledo, quedando el nombre desde los primeros tiempos de la fundación de la comunidad cuando los canónigos convivían bajo la regla de San Agustín. Estuvo destinado primeramente a la adquisición de ropas corales, concerniendo su contribución a la perfección, a diferencia del alimento que repartido por refectorio entre los miembros incumbía a la consunción. No servía así el vestuario, como las distribuciones, para premiar la asistencia a los actos corales, sino que respondía a la congrua sustentación de los residentes y sobre todo remuneraba a los canónigos, una minoría selecta y rectora que contribuiría a la perfección temporal y espiritual de la corporación, de ahí la cortedad en los días a los que se condicionaba la residencia anual exigida para ganarlo.

La dotación del vestuario se consolidó con las rentas de los diezmos de pan y vino de todo el arzobispado de Toledo, complementándose con otras rentas, que el Cabildo administró y controló cumpliendo con el compromiso contraído con la Iglesia para beneficiar y tratar la hacienda, garantizando así el objeto de la dotación. Para ello debió adaptarse a las exigencias del mercado, superando numerosos contratiempos, sobre todo marcados por la regulación del mercado del grano, que obligaría al Cabildo en momentos puntuales a cambiar la forma de hacer negocio con estas rentas y su adjudicación entre los canónigos. 


\section{FUENTES DOCUMENTALES}

ARChivo Catedral de Toledo (ACT):

Actas Capitulares (AC): vol.4, vol.5, vol.8, vol.12, vol.15 y vol.20.

Legajos: X.10.A.3.5., I.9.1.10., I.1.B.5.3. y A.9.I.1.1

Fondo de Obra y Fábrica (OF): OF-13, OF-527, OF-528, OF-909, OF1328, OF-1450, OF-1452, OF-1454, OF-1458 y OF-1459.

Apuntación: Libro segundo de horas de 1583, Libro primero de horas de 1593 y Libro Segundo de horas de 1593.

Fondo de secretaria (FS):

- Libro del oficio del repartidor del coro de la Santa Iglesia de Toledo.

- FS I, 2.

- Arcayos (copia), 2 vols.

BiblioteCA CATEDRAL DE TOLEDO (BCT):

ARCAYOS, Casos subcedidos en diversos tiempos en la Sancta Iglesia de Toledo desde el año 1435 sacados de los libros capitulares della. MS 42-29.

BibliOTECA DE CASTILLA LA MANCHA (BCLM):

Fondo Borbón-Lorenzana: MS. 449

\section{BIBLIOGRAFÍA}

AlCOCER, P. de (1554) Hystoria o descripcion de la imperial çibdad de Toledo. Edic. Facsímil. Toledo: IPET [1973].

BARRIO GonZALO, M. (1999) "La propiedad eclesiástica en la España del Antiguo Régimen", Ricardo RoBledo HeRnándeZ et al. (coord.) Historia de la propiedad en España (siglos XV-XX), Salamanca: Colegio de Registradores de la Propiedad y Mercantiles de España, Centro de Estudios Registrales, pp. 19-48.

CASAdo Alonso, H. (1980) La propiedad eclesiástica en la ciudad de Burgos en el siglo XV: el cabildo catedralicio. Universidad de Valladolid. 
CAVAllaRIO, D. (1850) Instituciones de Derecho Canónico, Traducción de Jorge Gisbert, 2 tomos, $3^{\text {a }}$ ed. Madrid-Santiago: Imprenta de don Alejandro Gómez Fuentenebro.

COVARRUBIAS OROZCO, S. (1611; 1995) Tesoro de la Lengua castellana o española. Madrid: Editorial Castalia.

Estella, E. (1926) "El fundador de la Catedral de Toledo", Boletín de la Real Academia de Bellas Artes y Ciencias Históricas de Toledo, 26-27, pp. 181-202.

FATJó GómEZ, P. (1999) "Organización y gestión de una hacienda eclesiástica en la Cataluña del XVII: la catedral de Barcelona", Revista de Historia Económica, 17, 1, pp. 89-119.

GómEZ ÁLVAREZ, U. (1996) Revisión histórica de la presión fiscal castellana (siglos XVI-XVIII). Universidad de Oviedo.

GómEZ-MENOR, J.C. (1970) Cristianos nuevos y mercaderes de Toledo. Notas y documentos para el estudio de la sociedad castellana del Siglo XVI. Toledo: Ed. Zocodover.

GonzÁlez Palencia, A. (1926-1930) Los mozárabes de Toledo en los siglos XII y XIII, 4 vols. Madrid: Instituto de Valencia de Don Juan.

GuAdaluPe BerazA, M.L. (1972) Diezmos de la sede toledana y rentas de la mesa arzobispal (siglo XV). Universidad de Salamanca.

GutiÉRREZ GaRCíA-BRAZALES, M. (1982) "La decimación en el arzobispado de Toledo (1508-1837)", Toletvm, 13, pp. 213-267.

HeRnÁndez, F.J. (1996) Los cartularios de Toledo. Catálogo documental, $2^{\mathrm{a}}$ ed. Madrid: Fundación Ramón Areces.

HERNÁNDEZ, J. y R. DONOSO (2008) "El sistema administrativo y contable de los diezmos de la diócesis de Sevilla en el siglo XVII", E. HERNÁNDEZ y B. PRIETO (coords.) Nuevos estudios sobre Historia de la Contabilidad. Burgos: Diputación Provincial, pp. 263-289.

LADERo QUeSADA, M.A. (1982) El siglo XV en Castilla. Fuentes de renta y política fiscal. Barcelona: Ariel.

Lanero Fernández, J. y E. ORTEGa MONTES (2005) "Naturaleza y significado de los libros de cuentas de John Isham, mercader de Isabel I, reina de Inglaterra", Pecvnia, 1, pp. 149-173.

- y - (2007) "De cómo rendir cuentas a Dios y a los hombres: las invocaciones sacras en los libros de cuentas del Renacimiento inglés", Pecvnia, 4, pp. 143-154. 
Le Goff, J. (2004) Mercaderes y banqueros de la Edad Media. Madrid: Alianza Editorial.

LOP OTíN, M.J. (2003) El cabildo catedralicio de Toledo en el siglo XV: Aspectos Institucionales y Sociológicos. Madrid: Fundación Ramón Areces.

Los códigos españoles concordados y anotados. Novísima recopilación de las leyes españolas, 12 tomos. Madrid: Imprenta de La Publicidad a cargo de D. M. Rivadeneyra (1850) Tomo 2 (libros 5, 6 y 7).

Montes Romero-Camacho, I. (1988) Propiedad y explotación de la tierra en la Sevilla de la Baja Edad Media. Sevilla: Fundación Fondo de Cultura de Sevilla.

Novísima Recopilación de las Leyes de España mandada formar por el señor don Carlos IV (1805-1807), 6 vols., $2^{\text {a }}$ ed. Madrid: Boletín Oficial del Estado, 1992. Reproducción facsímil.

Ordenanzas para el buen régimen y gobierno de la ciudad de Toledo. Toledo: A. Martín Gamero, 1858.

ORTIZ, B. (1549) Sumi Templi Toletani perquam graphica Descriptio, La Catedral de Toledo. Toledo: Antonio Pareja Editor [1999].

PISA, F. de (1605) Descripcion de la imperial ciudad de Toledo. Ed. Facsímil, Toledo: IPIET [1974].

RAMÓn PARRO, S. (1857; 1978) Toledo en la mano, 2 vols. Toledo: Imprenta y Librería de Severiano López Fando; Toledo: IPIET, ed. facsímil.

RiVERA RECIO, J.F. (1974) "Patrimonio y Señorío de Santa María de Toledo desde el 1086 hasta el 1208", Anales Toledanos, 9, pp. 117-182.

- (1976) La Iglesia de Toledo en el siglo XII (1086-1208), 2 vols. Roma: Publicaciones del Instituto Español de Historia Eclesiástica.

RODRÍGUEZ DE GRACIA, H. (2000) "Las tierras arzobispales en el Adelantamiento de Cazorla", Boletín del Instituto de Estudios Giennenses, 176, pp. 995-1.042.

RodríGUEZ LLOPIS, M. e I. GARCíA DíAz (1994) Iglesia y sociedad feudal. El cabildo de la catedral de Murcia en la Baja Edad Media. Universidad de Murcia.

RodRíGUeZ MOLINA, J. (1974) "El patrimonio eclesiástico del obispado de Baeza-Jaén (siglos XIII-XV)", Boletín de Estudios Giennenses, 82, pp. 974. 
SÁNCHEZ GONZÁLEZ, R. (2000) Iglesia y sociedad en la Castilla Moderna. El cabildo catedralicio de la Sede Primada (siglo XVII). Cuenca: Universidad de Castilla-La Mancha.

SANTAMARÍA LANCHO, M. (1982) "La organización de la gestión económica del cabildo catedralicio de Segovia. Siglos XIII-XIV", Estudios en memoria del Profesor D. Salvador de Moxó, II, pp. 505-540.

- (1985) "La explotación económica del patrimonio urbano del cabildo catedralicio de Segovia en el siglo XIV", La ciudad hispánica durante los siglos XIII-XIV. Madrid: Universidad Complutense, pp. 671-700.

SAnz SANCHo, I. (2000) "El cabildo catedralicio de Córdoba en la Edad Media", En la España Medieval, 23, pp. 189-245.

SuÁreZ, P. (1948) Historia del obispado de Guadix y Baza. Madrid: Artes Gráficas Arges.

TeJADA y RAmiRo, J. (1859-1863) Colección de cánones y de todos los Concilios de la Iglesia de España y de América, 5 tomos. Madrid: Imprenta de don Pedro Montero.

TRAVERSO RUIZ, F.M. (1987) "Los beneficiarios del diezmo gaditano (15911650)", Gades, 15, pp. 273-281.

VILLALUENGA DE GRACIA, S. (2009) "La remuneración y el control del servicio cultual en la Iglesia de Toledo (S. XVI)", Pecvnia, 8, pp. 325-370. 